\title{
Fc Engineering for Developing Therapeutic Bispecific Antibodies and Novel Scaffolds
}

\author{
Hongyan Liu't, Abhishek Saxena ${ }^{1 \dagger}$, Sachdev S. Sidhu ${ }^{1,2,3 *}$ and Donghui Wu ${ }^{1 *}$ \\ ${ }^{1}$ Laboratory of Antibody Engineering, Shanghai Institute for Advanced Immunochemical Studies, ShanghaiTech University, \\ Shanghai, China, ${ }^{2}$ Banting and Best Department of Medical Research, Terrence Donnelly Center for Cellular and \\ Biomolecular Research, University of Toronto, Toronto, ON, Canada, ${ }^{3}$ Department of Molecular Genetics, Terrence Donnelly \\ Center for Cellular and Biomolecular Research, University of Toronto, Toronto, ON, Canada
}

\section{OPEN ACCESS}

Edited by:

Tianlei Ying,

Fudan University, China

Reviewed by:

Thorsten Demberg, Immatics Biotechnologies,

Germany

Dimiter S. Dimitrov, National Institutes of Health (NIH),

USA

*Correspondence:

Sachdev S. Sidhu

sachdev.sidhu@utoronto.ca:

Donghui Wu

wudh@shanghaitech.edu.cn

tThese authors have contributed equally to this work.

Specialty section: This article was submitted to Vaccines and Molecular Therapeutics,

a section of the journal

Frontiers in Immunology

Received: 30 August 2016 Accepted: 10 January 2017 Published: 26 January 2017

Citation:

Liu H, Saxena A, Sidhu SS and Wu D (2017) FC Engineering for Developing Therapeutic Bispecific Antibodies and Novel Scaffolds. Front. Immunol. 8:38. doi: 10.3389/fimmu.2017.00038
Therapeutic monoclonal antibodies have become molecules of choice to treat autoimmune disorders, inflammatory diseases, and cancer. Moreover, bispecific/multispecific antibodies that target more than one antigen or epitope on a target cell or recruit effector cells ( $T$ cell, natural killer cell, or macrophage cell) toward target cells have shown great potential to maximize the benefits of antibody therapy. In the past decade, many novel concepts to generate bispecific and multispecific antibodies have evolved successfully into a range of formats from full bispecific immunoglobulin gammas to antibody fragments. Impressively, antibody fragments such as bispecific T-cell engager, bispecific killer cell engager, trispecific killer cell engager, tandem diabody, and dual-affinity-retargeting are showing exciting results in terms of recruiting and activating self-immune effector cells to target and lyse tumor cells. Promisingly, crystallizable fragment $(\mathrm{Fc})$ antigen-binding fragment and monomeric antibody or half antibody may be particularly advantageous to target solid tumors owing to their small size and thus good tissue penetration potential while, on the other hand, keeping Fc-related effector functions such as antibody-dependent cellular cytotoxicity, complement-dependent cytotoxicity, antibody-dependent cell-mediated phagocytosis, and extended serum half-life via interaction with neonatal $\mathrm{Fc}$ receptor. This review, therefore, focuses on the progress of $\mathrm{Fc}$ engineering in generating bispecific molecules and on the use of small antibody fragment as scaffolds for therapeutic development.

Keywords: mAbs, Fc region, FcRn, bispecific, monovalent, heterodimer, monomeric Fc, Fc antigen-binding

\section{INTRODUCTION}

Since approval of the first therapeutic monoclonal antibody (mAb) muromonab-CD3 by the United States Food and Drug Administration for treatment of organ transplant-associated acute rejections in 1992, a total of $62 \mathrm{mAbs}$ have been approved by the USFDA for clinical use as of May 2016 $(1,2)$. Therefore, the USFDA has approved an average of two to three mAbs each year over the last 25 years. Surprisingly, in 2015, a total of 10 mAbs were approved (2). Clearly, the demand for antibody molecules and global sales have been rising rapidly.

Most therapeutic mAbs are complete immunoglobulin gamma ( $\operatorname{IgG}$ ) molecules which consist of two heavy and two light chains that fold into a complex quaternary Y-shaped structure (1). The 
two arms of the Y-shaped molecule form the antigen-binding domains called antigen-binding fragment $(\mathrm{Fab})$ regions, and the stalk forms the crystallizable fragment $(\mathrm{Fc})$ region. Native IgG molecules can be digested by papain protease into separate $\mathrm{F}(\mathrm{ab})_{2}$ dimers and Fc domains (3). Fab arms are responsible for antigen binding and have been extensively engineered for developing highly specific and synthetic antibodies against numerous targets (4). The Fc region bears recognition motifs for binding innate immune receptors $[\mathrm{Fc} \gamma$ receptors (Fc $\mathrm{Rs}$ ), $\mathrm{C} 1 \mathrm{q}$, and neonatal $\mathrm{Fc}$ receptor $(\mathrm{FcRn})]$ on an effector cell and thus is responsible for mediating immune effector functions and in vivo IgG stability (5-11). This part has been a prime molecular engineering target for either enhancing or inhibiting the immune response including antibody-dependent cellular cytotoxicity (ADCC), complement-dependent cytotoxicity (CDC), and antibody-dependent cell-mediated phagocytosis (ADCP) $(9,12-14)$. Besides the Fab domain, antigen-binding character has also been engineered into the $\mathrm{Fc}, \mathrm{CH} 2$, and $\mathrm{CH} 3$ domains $(15,16)$. Such novel fragments have demonstrated therapeutic-like profiles in early studies and remain attractive ventures.

Antibody molecules can be made more efficient by engineering additional specificities so that multiple antigens or epitopes present on a cell can be targeted $(17,18)$. Extensive academic and industrial research in the past decade focused on developing bispecific Abs and Igs (bsAbs and bsIgs) and multispecific antibodies (e.g., TriMabs) (17-20).

Initially, bsAbs were generated by a quadroma technology, which required the somatic fusion of two hybridomas harboring different specificities $(21,22)$. This led to the foundation of bispecific antibody production for simultaneous targeting of two different antigens or epitopes on a cell (Figure 1A). However, these molecules suffered from low production yields, heterogeneity,

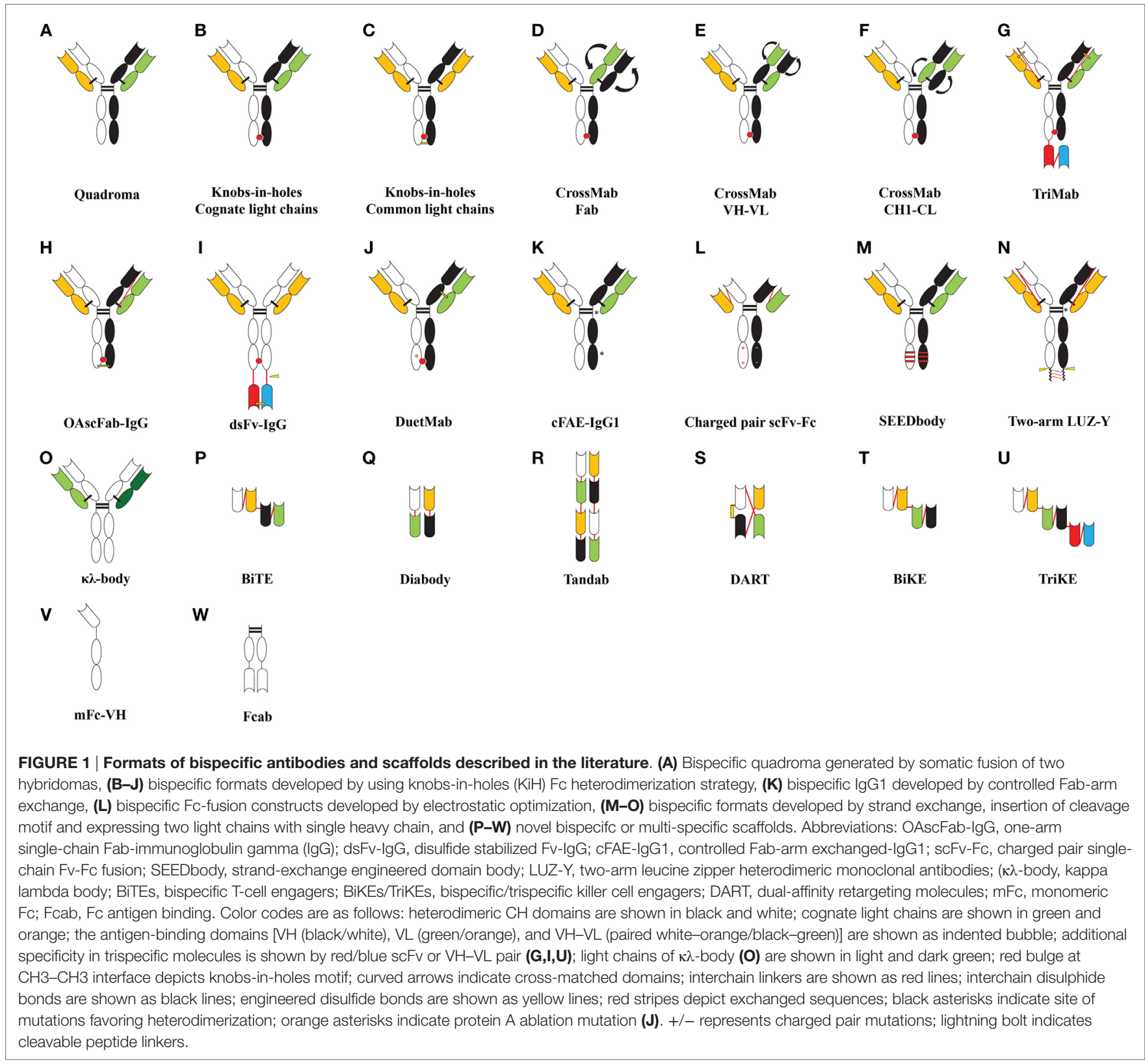


and human anti-mouse antibody (HAMA) response and therefore a decreased efficacy in patients (23). Nevertheless, one such bsAb EpCAM $\times$ CD3 (triomab; catumaxomab) was approved by the European Medicines Agency in 2009 for the treatment of patients with epithelial cancer-associated malignant ascites (24). Two additional bsAbs produced using the quadroma method, HER $2 \times$ CD3 (triomab; ertumaxomab) and CD20 $\times$ CD3 (triomab; FBTA05), are being evaluated in clinical trials for cancer treatment $(25,26)$.

Later, bsAb construction primarily relied on Fc heterodimerization by creating "knobs-in-holes" ( $\mathrm{KiH})$ mutations in the $\mathrm{CH} 3$ domain, which is prerequisite to assemble two half antibodies (common Fc heterodimer and unique $\mathrm{VH}-\mathrm{CH}$ and VL-CL domains) (27-29). However, a major bottleneck in this strategy has been the incorrect pairing of light-heavy chains. Consequently, newer strategies based on $\mathrm{KiH}$ and other platforms have been developed to circumvent faulty heavy and light chain pairing.

Small antibody fragments like nanobodies from llama and camel immune systems (30-33), single human domain antibodies (34-37), and single-chain variable fragments (scFvs) $(38,39)$ can be used to impart bispecificity or multispecificity to antibody molecules (18). Moreover, small non-immunoglobulin fragments like monoclonal lamprey antibodies (lambodies) (40), affibodies (41), and DNA/RNA aptamers $(42,43)$ can be fused with the antibody Fc fragment (homodimerization or heterodimerization) to have antibody-like properties such as Fc-associated effector functions (ADCC, CDC, and ADCP), extended pharmacokinetics and bispecificity $(44,45)$.

In this review, we describe recent advances in the therapeutic potential of bispecific molecules and small $\mathrm{Ab}$ fragments as novel scaffolds. We summarize the key breakthroughs achieved by employing and optimizing various strategies. Representative design, expression, purification, and purity of final bispecific molecules are summarized (see Table 1). Some bispecific antibodies and antibody fragments currently under clinical evaluation are listed (see Table 2), and graphical models of bispecific molecules under development are presented (see Figure 1).

\section{STRUCTURAL OPTIMIZATION}

The KiH (Figure 1B) concept was first proposed by Ridgway et al. (29) to develop Fc heterodimers. It allows the generation of complementary interacting interfaces by manipulating key amino acid residues that participate in the Fc dimeric interaction. Amino acids with small side chain are replaced by ones with larger side chains, thereby creating a knob or protrusion in one chain and vice versa to create a hole or socket in the partner chain. Traditionally, a T366Y mutation in one $\mathrm{CH} 3$ domain has been used to create a knob while an Y407T mutation in the other $\mathrm{CH} 3$ domain (hereafter denoted as $\mathrm{Y}_{407} \mathrm{~T}$ T) gives rise to a hole (29). Such mutations establish intermolecular interactions and promote the heterodimer formation due to knob/hole pairing and bring about the association of two different Fab regions to give rise to a monovalent bsIg. It was also found that complementing existing knob/hole mutations with F405A and T394'W on the knob and hole side, respectively, yielded $92 \%$ molecules as heterodimers
(29). In an effort to further improve and stabilize the $\mathrm{KiH}$ model, a phage-displayed library of $\mathrm{CH} 3$ (T366W) knob domain and $\mathrm{CH} 3$ (randomized at $366^{\prime}, 368^{\prime}$ and $407^{\prime}$ ) hole domain was created by fusing FLAG-tagged $\mathrm{CH} 3$-hole to the $\mathrm{N}$-terminal region of the gene-III minor coat protein of M13 bacteriophage (27). The heterodimers were selected by an anti-FLAG antibody and were found to be completely diverse from parent T366W-Y407'A clone. Phage display optimized variants existed preferably as heterodimers and exhibited greater stabilities (27).

The $\mathrm{KiH}$ concept suffered from mispairing of heavy and light chains in the heterodimers. Merchant et al. (28) suggested using identical light chains for both Fab domains, which can be further stabilized by engineered disulfide bonds (Figure 1C). They employed a scFv phage-displayed library with restricted light chain usage to identify antibodies recognizing c-MPL and HER3 using common light chains and developed a bispecific c-MPL $\times$ HER3 antibody with approximately $95 \%$ heterodimer recovery (28).

However, it is not always possible to use a common light chain for developing bispecific molecules because antigen recognition can critically rely on the partner light chain $(73,74)$. To circumvent the existing light chain mispairing in bsIgs, a methodology termed as "CrossMab" (47) was developed and combined with the $\mathrm{KiH}$ technology. In principle, "CrossMab" is achieved by the exchange between heavy and light chains of the Fab portion of one partner in order to generate formats of "CrossMab Fab" (Figure 1D), "CrossMab VH-VL" (Figure 1E), or "CrossMab CH1-CL” (Figure 1F) (47). Such bispecific formats clearly reduced the heavy-light chain mispairing, allowed simultaneous recognition of the two antigens (VEGF-A and Ang2), retained the affinity and stability profiles of the parent antibodies and exhibited antiangiogenic and antitumor activity in vivo (47).

Similarly, trispecific antibodies "TriMabs" (Figure 1G) were developed and combined with the $\mathrm{KiH}$ technology using $\mathrm{N}$-terminal single-chain $\mathrm{Fab}$ (scFab) and C-terminal scFv fusions of Fc region, which avoids the light chain mispairing. The concept was demonstrated by using four specificities (EGFR, IGFR, cMET, and HER3) incorporated into three structural formats (19). TriMabs 1 and 2 engage their respective antigen in a monovalent manner while TriMab 3 binds HER3 in a bivalent fashion. These molecules retained their ability to bind individual antigens and shared kinetic properties with their parent molecules. Besides, the TriMabs were also shown to simultaneously recognize their respective antigens when immobilized on a chip or expressed on human pancreatic adenocarcinoma cells (BXPC-3) and inhibited receptor signaling and tumor growth (19).

An scFab heterodimeric bsIg format (OAscFab-IgG) (Figure 1H) with anti-IGF1R and anti-EGFR specificities has also been described to prevent faulty chain pairing (48). The light chains in the scFab format were attached to the N-terminus of the heavy chain through a 32-residue linker, and heterodimer formation was achieved by $\mathrm{KiH}$ mutations. This strategy allowed the recovery of $99 \%$ pure heterodimers, which exhibited comparative antigen-binding affinity to the parent antibodies (48).

Further, a conditional functionality was engineered in a bispecific molecule which relied on proteolytic cleavage to generate functional binders. The VH and VL domains incorporating C44 


\begin{tabular}{|c|c|c|c|c|c|c|}
\hline $\begin{array}{l}\text { Strategy/ } \\
\text { format }\end{array}$ & Mutation & Target & $\begin{array}{l}\text { Bispecificity } \\
\text { analysis/yield (\%) }\end{array}$ & $\begin{array}{l}\text { Protein expression/purification/ } \\
\text { yield (g/L) }\end{array}$ & Remarks & Reference \\
\hline Quadroma & NA & $\begin{array}{l}\text { EpCAM } \times \text { CD3, HER3 } \times \text { CD3 } \\
\text { CD20 } \times \text { CD3 }\end{array}$ & $\begin{array}{l}\text { lon-exchange } \\
\text { chromatography and } \\
\text { SEC/12.5\% }\end{array}$ & Hybridoma/protein A & $\begin{array}{l}\text { Associated human } \\
\text { anti-mouse antibody } \\
\text { response }\end{array}$ & $(26,46)$ \\
\hline Knobs-in-holes & $\begin{array}{l}\text { T366W/T366Y (knobs) and T366S/L368A } \\
\text { T394W/F405AY407V(T) (holes) }\end{array}$ & $\begin{array}{l}\mathrm{CD} 3 \times \mathrm{CD} 4, \mathrm{c}-\mathrm{MPL} \times \mathrm{HER} 3, \\
\text { VEGF-A } \times \text { Ang2, CD20 } \times \mathrm{hL} 243 \gamma 1, \\
\text { EGFR } \times \text { IGF } 1 \mathrm{R}, \mathrm{HER} 3 \times \mathrm{CMET}, \\
\mathrm{CD} 3 \times \text { EpCAM, CD3 } \times \text { HER2, } \\
\text { EGFR } \times \text { HER2, CD4 } \times \text { CD70, } \\
\text { MET } \times \text { EGFR }\end{array}$ & $\begin{array}{l}\text { Electroblotting, SLD, SEC, } \\
\text { MS-TOF (73-100\%) }\end{array}$ & $\begin{array}{l}\text { HEK293, Escherichia coli, and cell-free } \\
\text { expression system/protein A, DEAE, } \\
\text { and Mab Select Sure/0.004-1.0 g/L }\end{array}$ & $\begin{array}{l}\text { Faulty light and heavy } \\
\text { chain pairing }\end{array}$ & $\begin{array}{l}(19,27-29, \\
47-53)\end{array}$ \\
\hline $\begin{array}{l}\text { Biochemical } \\
\text { optimization }\end{array}$ & $\begin{array}{l}\mathrm{S} 364 \mathrm{H} / \mathrm{F} 405 \mathrm{~A}(\mathrm{CH} 3 \mathrm{~A}) \text { andY349T/T394F } \\
(\mathrm{CH} 3 \mathrm{~B})\end{array}$ & $\mathrm{CD} 16 \times \mathrm{HER} 2$ and $\mathrm{CD} 3 \times \mathrm{HER} 2$ & HPLC/SEC (89\%) & $\begin{array}{l}\text { HEK293F/protein A, nickel affinity } \\
\text { chromatography }\end{array}$ & & (54) \\
\hline $\begin{array}{l}\text { Biochemical } \\
\text { optimization }\end{array}$ & $\begin{array}{l}\text { L368E/K409R (CH3), R221E/R228E } \\
\text { (lgG1-hinge), and R223E/R225E/R228E } \\
\text { (lgG2-hinge) }\end{array}$ & CD3 $\times$ CD2O, EGFR $\times$ ErbB2 & $\begin{array}{l}\text { lon-exchange } \\
\text { chromatography and LCMS } \\
(65-100 \%)\end{array}$ & $\begin{array}{l}\text { HEK293/protein Alin vitro cell-free } \\
\text { assembly }\end{array}$ & Cognate chain pairing & (55) \\
\hline $\begin{array}{l}\text { Biochemical } \\
\text { optimization }\end{array}$ & P228S (IgG1-hinge) and F405L/K409R (CH3) & CD20 $\times$ EGFR & ESI-MS (95.7\%) & HEK293/protein A/SEC/473.4 g/L & High yield and efficiency & (56) \\
\hline $\begin{array}{l}\text { Biochemical } \\
\text { optimization }\end{array}$ & H435R and Y436F (IgG1-CH3) & $\mathrm{CD} 20 \times \mathrm{CD} 3$ & SEC (100\%) & Stable CHO-K1/protein A/0.2-0.3 g/L & Cognate chain pairing & $(57,58)$ \\
\hline $\begin{array}{l}\text { Biochemical } \\
\text { optimization }\end{array}$ & $\begin{array}{l}\mathrm{S} 354 \mathrm{C}(\mathrm{CH} 3 \mathrm{~A}), \mathrm{Y} 394 \mathrm{C}(\mathrm{CH} 3 \mathrm{~B}), \mathrm{F} 126 \mathrm{C} \\
(\mathrm{CH} 1), \mathrm{S} 121 \mathrm{C}(\mathrm{LC}), \mathrm{C} 44(\mathrm{VH}) \text {, and C100 (VL) }\end{array}$ & $\begin{array}{l}\text { EGFR } \times \text { IGF1R, CD20 } \times \text { hL243 } \gamma 1 \text {, } \\
\text { HER3 } \times \text { cMET }\end{array}$ & MS-TOF, SEC (73\%) & HEK293/protein A/0.004-0.03 g/L & $\begin{array}{l}\text { Prevent homodimer } \\
\text { formation }\end{array}$ & $(49,52,53)$ \\
\hline $\begin{array}{l}\text { Biochemical } \\
\text { optimization }\end{array}$ & $\begin{array}{l}\text { F241R, F243S, F241S, F243R (CH2) and } \\
\text { C226S, C229S (hinge) }\end{array}$ & NA & MS-TOF (90\%) & E. coli/protein A & $\begin{array}{l}\text { Avoid covalent bonding } \\
\text { of heterodimers }\end{array}$ & (50) \\
\hline $\begin{array}{l}\text { Electrostatic } \\
\text { optimization }\end{array}$ & $\begin{array}{l}\text { K409D (CH3A), D399R (CH3B), K409E } \\
\text { (CH3A), D399K (CH3B), and K409E (CH3A), } \\
\text { D399R (CH3B) }\end{array}$ & CD3 $\times$ TARTK & LC/MS (98\%) & HEK293/Select Sure column and SEC & $\begin{array}{l}\text { Prevent homodimer } \\
\text { formation }\end{array}$ & (59) \\
\hline $\begin{array}{l}\text { Electrostatic } \\
\text { optimization }\end{array}$ & $\begin{array}{l}\text { K409W, K360E, K370E (CH3A) and D399V, } \\
\text { F405T, Q347R, E357N, S364B (CH3B) }\end{array}$ & VEGFR-2 $\times$ MET & SEC (80-90\%) & HEK293/protein A & $\begin{array}{l}\text { Prevent homodimer } \\
\text { formation }\end{array}$ & $(60,61)$ \\
\hline $\begin{array}{l}\text { Electrostatic } \\
\text { optimization }\end{array}$ & $\begin{array}{l}\text { Q39K, Q105K (VH), S183D (CH1), Q38D } \\
\text { (VL), S176D (CL), K392D, K409D (CH3A), } \\
\text { and E356K, D399K (CH3B) }\end{array}$ & HER2 $\times$ EGFR & SEC (100\%) & Stable $\mathrm{CHO} /$ protein A/0.2-0.3 g/L & Cognate chain pairing & (57) \\
\hline $\begin{array}{l}\text { Electrostatic } \\
\text { optimization }\end{array}$ & $\begin{array}{l}\text { T350V, L351Y, F405A, Y407V (CH3A) and } \\
\text { T350V, T366L, K393L, T394W (CH3B) }\end{array}$ & HER2 $\times$ ErbB2 & SEC (95\%) & $\mathrm{CHO} /$ protein A/0.25 g/L & $\begin{array}{l}\text { Improved biophysical } \\
\text { properties }\end{array}$ & (62) \\
\hline$\kappa \lambda$-body & NA & CD19 × CD47, CD47 × EpCAM & Isoelectric focusing/41.5\% & $\begin{array}{l}\text { PEAK cells/protein A, CaptureSelect } \\
\text { immunoglobulin gamma (lgG)-CH1, } \\
\text { KappaSelect, and LambdaFabSelect } \\
\text { affinity chromatography/1.5 g/L }\end{array}$ & $\begin{array}{l}\text { Exploits variable light } \\
\text { chains for generating } \\
\text { bispecifics }\end{array}$ & (63) \\
\hline
\end{tabular}




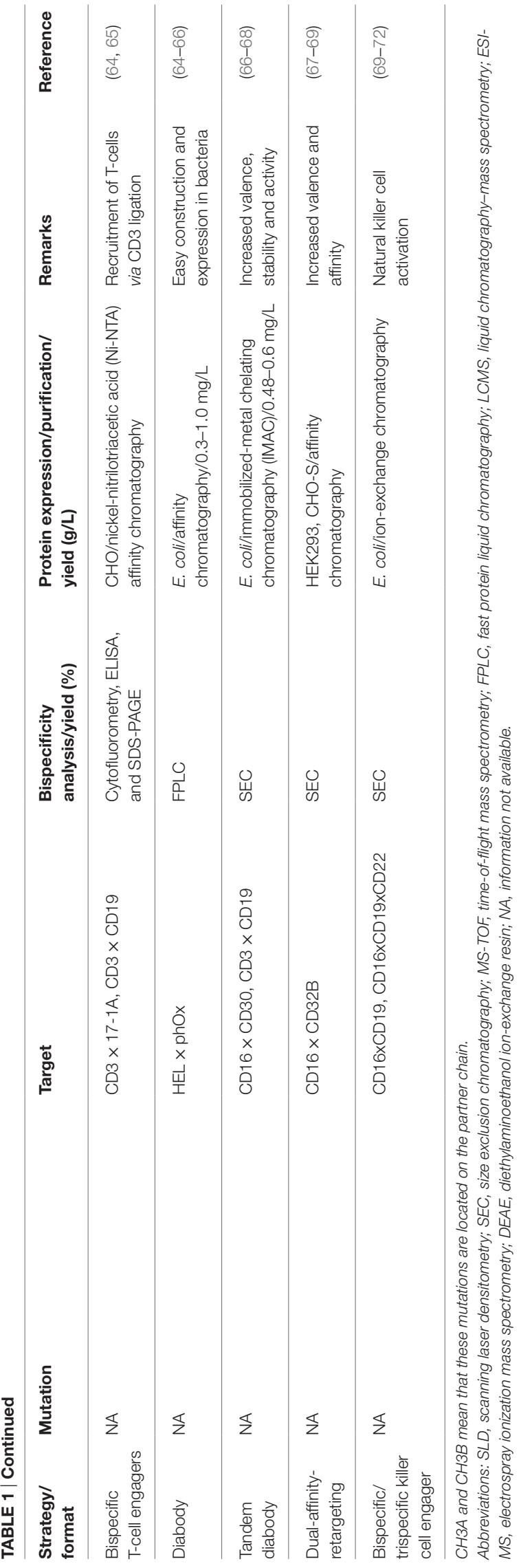

or $\mathrm{C} 100$ mutations, respectively, were attached to the C-termini of the Fc region in knob and hole mutant, respectively, via a flexible linker. The VH C44 and VL C100 generate a disulfide stabilized Fv (Figure 1I), bypassing the requirement of a VH-VL linker to promote heterodimer formation in such an arrangement (49). Here, the C-terminal attachment does not affect off-rate and instead relieves steric hindrance after proteolytic cleavage. This methodology can be applied to express toxic products in an inactive state in a cell which can be activated later during the processing steps by proteolytic cleavage (49). This design incorporated a proteolytic motif for Pre-Scission within the peptide linker on one of the partner chains. The recognition motif for other proteolytic systems like furin, matrix metalloproteinase-2/9, or urinary plasminogen activator can also be engineered for varying applications (49).

Next, a structure-guided approach was used to generate bsIg by separately expressing monomeric IgG (harboring KiH mutations) in Escherichia coli. Equimolar amounts of two monomeric IgGs, when mixed together at a basic $\mathrm{pH}$, resulted mostly in heterodimeric IgGs (50). These constructs also incorporated mutations in $\mathrm{CH} 2$ domain residues (F241R/F243S or F241S/F243R) which remain solvent exposed in aglycosylated IgG molecules and the hinge region (C226S/C229S) to avoid covalent association of $\mathrm{knob} / \mathrm{knob}$ or hole/hole monomers (50).

Recently, Xu et al. (51) utilized a cell-free expression system to generate bsIg based on $\mathrm{KiH}$ format. They used anti-CD3, anti-EpCAM, and anti-HER2 antibodies to generate eight bsIgs in four different $\mathrm{KiH}$ scaffolds. Among these scaffolds, scFv-KiH and $\mathrm{scFv}-\mathrm{KiH}^{\mathrm{r}}$ (reverse) exhibited superior yields. Moreover, this system allowed optimal heterodimer expression by using equimolar plasmid ratios with an insignificant amount of free chains (51). The Fc fragments with a hole were found to be more stable than Fc-knob, and it was suggested to fuse difficult-to-express proteins to Fc-hole for high-level of expression (51).

Using the KiH platform, Mazor et al. (52) introduced two cysteine pairs in the $\mathrm{CH} 1-\mathrm{CL}$ interface of one of the Fab arm to create disulfide bonds for correct light chain pairing. Almost $100 \%$ monovalent bsIg was recovered from variant with $\mathrm{CH} 1$ (F126C) and CL (S121C) mutations. These mutations were applied to construct EGFR $\times$ HER2 and CD4 $\times$ CD70 "DuetMabs" (Figure 1J) (52) and were shown to be devoid of any free chains or fragments and had a molecular mass similar to native IgG. The thermal stabilities of EGFR $\times \operatorname{HER} 2\left(T_{\mathrm{m}}=55^{\circ} \mathrm{C}\right)$ and $\mathrm{CD} 4 \times \mathrm{CD} 70\left(T_{\mathrm{m}}=58^{\circ} \mathrm{C}\right)$ antibodies were comparable to the parental antibodies. DuetMabs could simultaneously engage their targets and as a result $\mathrm{CD} 4 \times \mathrm{CD} 70$ DuetMab preferentially recognized $\mathrm{CD} 4^{+} \mathrm{CD} 70^{+} \mathrm{T}$ cells over $\mathrm{CD} 4^{+} \mathrm{CD} 70^{-}$or $\mathrm{CD} 4^{-} \mathrm{CD} 70^{+}$ T cells. Similarly, the EGFR $\times$ HER2 molecule shared binding kinetics with parental antibodies and also exhibited normal binding to FcyRs, C1q, and FcRn (52).

Based on multistate designs involving molecular modeling, $\mathrm{X}$-ray crystallography validation, and rounds of iteration, Lewis and coworkers (75) identified several favorable mutants across the interface of $\mathrm{VH}-\mathrm{VL}$ and $\mathrm{CH} 1-\mathrm{CL}$ for formation of an orthogonal Fab interface. In combination with previously reported Fc mutations in favor of the $\mathrm{Fc}$ heterodimerization (59), five bsIgs were correctly assembled from six parental mAbs with an average of 


\begin{tabular}{|c|c|c|c|c|c|c|}
\hline & Format & Strategy & Target & Clinical development phase & Disease & Company \\
\hline \multicolumn{7}{|c|}{ bsAb/bsAb Fragment } \\
\hline Catumaxomab & Triomab & Quadroma & $\mathrm{EpCAM} \times \mathrm{CD} 3$ & $\begin{array}{l}\text { Approved by European Medicines Agency } \\
\text { Phase-2 (NCT00189345) } \\
\text { Phase-2 (NCT01504256) } \\
\text { Phase-2 (NCT01246440) }\end{array}$ & $\begin{array}{l}\text { EpCAM+ tumor; malignant ascites } \\
\text { Platinum refractory epithelial ovarian } \\
\text { carcinoma } \\
\text { Gastric adenocarcinoma } \\
\text { Ovarian cancer }\end{array}$ & $\begin{array}{l}\text { Neovii Biotech } \\
\text { AGO Study Group } \\
\text { AlO-Studien-gGmbH } \\
\text { Grupo Espanol de Investigacion } \\
\text { en Cancer de Ovario }\end{array}$ \\
\hline Ertumaxomab & Triomab & Quadroma & $\mathrm{HER} 2 \times \mathrm{CD} 3$ & $\begin{array}{l}\text { Phase-1/2 (NCT01569412) } \\
\text { Phase-2 (NCT00351858) } \\
\text { Phase-2 (NCT00452140) } \\
\text { Phase-2 (NCT00522457) }\end{array}$ & $\begin{array}{l}\text { Her2/Neu+ advanced solid tumor } \\
\text { Advanced metastatic breast cancer }\end{array}$ & $\begin{array}{l}\text { Krankenhaus Nordwest } \\
\text { Neovii Biotech }\end{array}$ \\
\hline FBTA05 & Triomab & Quadroma & $\mathrm{CD} 20 \times \mathrm{CD} 3$ & Phase-1/2 (NCT01138579) & CLL & Technische Universitat Munchen \\
\hline RO695688 & Crossmab & $\begin{array}{l}\text { Knobs-in- } \\
\text { holes }(\mathrm{KiH})\end{array}$ & $\mathrm{CEA} \times \mathrm{CD} 3$ & Phase-1 (NCT02324257) & Advanced metastatic $\mathrm{CEA}^{+}$solid tumors & Hoffmann-La Roche \\
\hline RO5520985 & Crossmab & $\mathrm{KiH}$ & Ang2 $\times$ VEGFA & Phase-1 (NCT01688206) & Advanced or metastatic solid tumors & Hoffmann-LA Roche \\
\hline RO5520985 & Crossmab & $\mathrm{KiH}$ & Ang2 $\times$ VEGFA & $\begin{array}{l}\text { Phase-2 (NCT01688206) } \\
\text { Phase-2 (NCT02484690) }\end{array}$ & $\begin{array}{l}\text { Advanced or metastatic solid tumors } \\
\text { AMD }\end{array}$ & $\begin{array}{l}\text { Hoffmann-La Roche } \\
\text { Hoffmann-La Roche }\end{array}$ \\
\hline RG7813 & scFv-lgG & NA & $\mathrm{CEA} \times \mathrm{IL}-2$ & Phase-1 (NCT02004106) & Advanced metastatic $\mathrm{CEA}^{+}$solid tumors & \\
\hline MM-141 & scFv-lgG & NA & IGF $\times$ HER3 & $\begin{array}{l}\text { Phase-1 (NCT01733004) } \\
\text { Phase-2 (NCT02399137) }\end{array}$ & $\begin{array}{l}\text { Advanced solid tumor } \\
\text { Metastatic pancreatic cancer }\end{array}$ & $\begin{array}{l}\text { Merrimack Pharmaceuticals } \\
\text { Merrimack Pharmaceuticals }\end{array}$ \\
\hline MOR209/ES414 & scFv-lgG & NA & $\mathrm{PSMA} \times \mathrm{CD} 3$ & Phase-1 (NCT02262910) & Metastatic prostate cancer & Aptevo Therapeutics \\
\hline LY3164530 & Ortho-Fab lgG & $\begin{array}{l}\text { Structural } \\
\text { optimization }\end{array}$ & MET $\times$ EGFR & Phase-1 (NCT02221882) & Metastatic neoplasm & Eli Lilly and Company \\
\hline ALX-0061 & Nanobody & NA & $\mathrm{IL}-6 \mathrm{R} \times \mathrm{HSA}$ & Phase-2 (NCT01284569) & Rheumatoid arthritis & Ablynx \\
\hline ATN-103 & Nanobody & NA & TNF $\times$ HSA & Phase-2 (NCT01063803) & Rheumatoid arthritis & Ablynx \\
\hline Blinatumomab & $\begin{array}{l}\text { Bispecific T-cell } \\
\text { engager BiTE }\end{array}$ & NA & $\mathrm{CD} 3 \times \mathrm{CD} 19$ & $\begin{array}{l}\text { Approved by Food and Drug Administration } \\
\text { Phase-1 (NCT00274742) } \\
\text { Phase-2 (NCT01207388) } \\
\text { Phase-2 (NCT01209286) } \\
\text { Phase-1 (NCT02568553) } \\
\text { Phase-2 (NCT02143414) } \\
\text { Phase-3 (NCT02003222) }\end{array}$ & $\begin{array}{l}\text { ALL } \\
\text { Relapsed NHL } \\
\text { Residual ALL } \\
\text { Relapsed/refractory ALL } \\
\text { Relapsed NHL } \\
\text { ALL } \\
\text { BCR-ABL-/ B-cell lineage ALL }\end{array}$ & $\begin{array}{l}\text { Amgen } \mathrm{GmbH} \\
\text { Amgen } \mathrm{GmbH} \\
\text { Amgen } \mathrm{GmbH} \\
\text { Amgen } \mathrm{GmbH} \\
\text { National Cancer Institute } \\
\text { National Cancer Institute } \\
\text { National Cancer Institute }\end{array}$ \\
\hline Solitomab & BiTE & NA & CD3 $\times$ EpCAM & Phase-1 (NCT00635596) & Advanced solid tumors & Amgen GmbH \\
\hline AMG330 & BiTE & NA & $\mathrm{CD} 33 \times \mathrm{CD} 3$ & Phase-1 (NCT02520427) & AML & Amgen GmbH \\
\hline
\end{tabular}

$\mathrm{CD} 33 \times \mathrm{CD} 3$ 
93\% success rate (75). More recently, Leaver-Fay and coworkers (76) furthered the multistate design strategy by construction of a negative state pool across the $\mathrm{CH} 3$ interface via protein docking and sequence design. Several novel mutants were discovered to favor the formation of $\mathrm{Fc}$ heterodimerization with a purity of more than $90 \%$ (76). In combination with the orthogonal Fab interface, four fully bsIgs could be correctly formed with an average success rate of more than $93 \%$ in one-step process (76).

$\mathrm{CH} 1-\mathrm{CK}$ heterodimeric scaffold can be used to build bispecific molecules $(77,78)$. However, it is known that the CH1-CK pair alone is not strong enough to form a stable heterodimer and $\mathrm{CH} 1-\mathrm{CK}$ pair requires cooperation from $\mathrm{VH}-\mathrm{VL}$ pair for a stable heterodimer assembly $(79,80)$. To improve the $\mathrm{CH} 1-\mathrm{CK}$ heterodimerization in the absence of VH-VL pair cooperation, Chen et al. employed structure-based design in combination with phage display directed evolution (81). They identified that a S66V mutation in the $\mathrm{CH} 1$ domain together with a S69L in the CK domain can stabilize $\mathrm{CH} 1-\mathrm{CK}$ heterodimerization and increase the in vivo serum half-life of a previously described CD4-antibody fusion protein $(4 \mathrm{Dm} 2 \mathrm{~m})$, which targets the CD4-induced (CD4i) coreceptor binding site of the human immunodeficiency virus (HIV) 1 envelope glycoprotein 120 (81-84). It seems that this $\mathrm{CH} 1-\mathrm{CK}$ stabilization may increase the overall stability of $4 \mathrm{Dm} 2 \mathrm{~m}$ and thus improve its pharmacokinetics. Moreover, the strengthened $\mathrm{CH} 1-\mathrm{CK}$ heterodimerization may pave the way for construction of bispecific molecules based on this scaffold (81).

\section{BIOCHEMICAL OPTIMIZATION}

A structure and sequence guided approach identified low energy amino acid pairs in the $\mathrm{CH} 3$ domain, which could promote heterodimer formation (54). These mutations were engineered into the design of a new library, which increased the heterodimer yield up to $89 \%$. The strategy was applied to either $\mathrm{Fc} /$ single-chain $\mathrm{Fv}-\mathrm{Fc}$ fusion $(\mathrm{scFv}-\mathrm{Fc})$ or scFv-Fc formats utilizing two different $\mathrm{CH} 3$ domains favoring heterodimer formation to generate CD16 $\times$ HER2 bispecific, which exhibited improved antitumor attributes against the breast cancer cell line SKBr3 in the presence of $\mathrm{CD} 6^{+}$natural killer (NK) cells from human peripheral blood mononuclear cells (PBMCs) (54).

In another approach, Strop et al. (55) developed bispecific IgG1 and IgG2 antibodies by oxidation/reduction methodology for chain pairing. They described bispecific mutations (K409 and L368) in the CH3 domain, which allowed the development of bsIg either by coexpressing monomers bearing common light chains or by mixing the purified monomers under mild reducing conditions. Highest bispecificity was achieved by complementing K409/L368 with either IgG1-hinge or IgG2-hinge mutations (55). A CD3 $\times$ CD20 bsIg so generated showed in vitro cytotoxicity against mouse B-cell lymphoma in the presence of freshly isolated mouse primary $\mathrm{T}$ cells. Further, the bsIg mediated a dosedependent lysis of target cells and also depleted $\mathrm{CD} 20^{+} \mathrm{B}$ cells in vivo by $\mathrm{T}$-cell engagement (55).

A similar concept to generate IgG1 bispecific molecules was applied by Labrijn et al. (56). They incorporated a P228S hinge mutation which makes bonds more susceptible to cleavage under reducing conditions and additional mutations in separate human 
IgG1-CH3 domains to promote Fab-arm exchange. Two mutated antibodies in IgG1 format (anti-EGFR and anti-CD20) were expressed separately and then mixed together in the presence of reducing agent, which resulted in 96\% efficient Fab-arm exchange (Figure 1K) (56). The bispecific molecules so generated were stable at $5^{\circ} \mathrm{C}$ for over a period of 6 months and had comparable pharmacokinetics to their parent antibodies. A dual targeting CD3 $\times$ HER2 bispecific IgG1 was also constructed and showed a great enhancement in the $\mathrm{T}$ cell-mediated cytotoxicity against breast adenocarcinoma cells (AU565) in comparison to control antibody and in vivo tumor growth inhibition in an adoptive transfer xenograft model of gastric carcinoma with freshly prepared human PBMCs (56).

\section{ELECTROSTATIC OPTIMIZATION}

Gunasekaran et al. (59) exploited charged pair based attraction/repulsion in different $\mathrm{Fc}$ chains in the $\mathrm{scFv}-\mathrm{Fc}$ format (Figure 1L). They identified conserved oppositely charged residues in the $\mathrm{CH} 3-\mathrm{CH} 3$ domain interface (D356-K439', E357-K370', K392-D399', and D399-K409'). Among these, the D399-K409' pair is buried and contributes to $\mathrm{CH} 3-\mathrm{CH} 3$ interaction. Mutations in these key residues (K409D-D399' K, K409D-D399'R, K409E-D399'K, and K409E-D399'R) favored greater than $90 \%$ heterodimer formation (59). The strategy was applied to generate a CD3 $\times$ TARTK bsAb and shown to kill U87-TARTK ${ }^{+}$human glioma cell line by CD3 ligation in the presence of human PBMCs (59).

Similarly, Choi et al. (60) substituted conserved and charged amino acids from the core of the $\mathrm{CH} 3$ domain with hydrophobic residues to perturb the structural symmetry and designed longrange electrostatic attraction at the edge of the $\mathrm{CH} 3$ domain to promote heterodimer formation. A "W-VT" $\mathrm{CH} 3$ mutant pair (K409W and D399'V/F405'T) and "ER" CH3 mutant pair (K360E and $\mathrm{Q} 347^{\prime} \mathrm{R}$ ) accounted for 77 and 53\% heterodimer species, respectively. This was attributed to the disruption of electrostatic and hydrophobic interactions and increased steric hindrance due to the K409W-F405'T mutations (60). Further, the combination of W-VT and ER mutant increased heterodimer formation up to $91 \%$, enhanced binding to FcRn and imparted parent-like thermal stability. The "ERW-VT" mutant was used to generate MET $\times$ VEGFR-2 bispecific scFv (bscFv)-Fc, which bound more strongly to HUVEC cells and inhibited cell growth and VEGF/ HGF-mediated ERK/AKT signaling. The MET $\times$ VEGFR-2 bsAb induced a twofold greater reduction in tumor volume in MKN45 human gastric cancer xenograft models compared to parent antibodies (60).

Subsequently, Fc heterodimer mutants were isolated based on displayed $(\mathrm{CH} 3 \mathrm{~A})$ or secreted $(\mathrm{CH} 3 \mathrm{~B})$ yeast libraries from either W-VT mutant or wild-type Fc incorporating K370-E357'/S364' or D399-K392'/K409' interaction pairs. The haploid yeast cells carrying individual libraries upon mating resulted in a diploid cell harboring both Fc variants, which if heterodimerized were displayed on the cell surface (61). In addition, these Fc variants carried C228S/C231S mutations to prevent homodimer formation and N297Q to avoid hypermannosylation in yeast (61).
Further, structure-guided design assisted with the computational algorithm and optimized energy function in between the partner chains were used to improve biophysical properties of bsIg molecules. Identified mutations [ZW1-Chain A (T350V/ L351Y/F405A/Y407V) and Chain B (T350V/T366L/K393L/ T394W)], which favor pure heterodimer formation (95\%) and stability comparable to the wild-type Fc, were applied to create bispecific molecules (62). These mutations greatly improved the stability of the heterodimer when exposed to heat, acid, base, agitation, oxidation, freeze-thaw, and varying $\mathrm{pH}$ (62).

Electrostatic interactions were also optimized for the correct pairing of the heavy chain and its cognate light chain when coexpressed in the same cell. To achieve this, structure-guided mutations were made by replacing polar or hydrophobic residues of the CH1-CL and VH-VL interfaces with charged amino acids. These mutations promoted correct pairing of the heavy and light chains due to the maximization of electrostatic interactions over H-bonding and Van der Waals forces. The HER $2 \times$ EGFR bsIg induced a greater receptor internalization than achieved by the combination of parental antibodies and, furthermore, exhibited enhanced capability to inhibit BXPC-3, PANC-1, and Calu-3 tumors in xenograft models (57).

\section{CONCEPTUAL ADVANCES}

Davis et al. (85) exploited the sequence diversity in $\mathrm{CH} 3$ domains of IgG and IgA ( $47 \%$ diverse in humans) and proposed that if diverse patches of IgG and IgA CH3 domains are mutually replaced then they can be heterodimerized (85). This strategy resulted in a unique complementarity among the $\mathrm{CH} 3-\mathrm{CH} 3$ interface. It was experimentally shown by constructing a strand-exchange engineered domain body (SEEDbody) fusion protein [IgG1hinge- $\mathrm{CH} 2-(\mathrm{SEED}-\mathrm{IgA}-\mathrm{CH} 3)]$, which preferentially associated into heterodimers (85-95\%) (85). Depending on the patched sequence, these molecules were referred to as either AG or GA SEED. Further, novel SEEDbodies (Figure 1M) retained normal $\mathrm{FcRn}$ and protein A binding due to a specific motif introduced from IgG into the IgA. The major advantage of SEEDbody is to engineer additional specificity via scFv fused to the N-terminus of the SEEDbody, which overcomes the faulty light chain pairing (85).

Antibody scaffolds have also been used to develop bispecific pharmacophore fusions "COVX-Bodies" by chemical optimization of bsAbs (86). The principle involved here is to chemically link two pharmacophore peptides via branched azetidinone linker followed by an irreversible site-specific covalent fusion to the scaffold antibody. The azetidinone linker interacts with the K94 of Ig heavy chain and establishes an amide bond with the

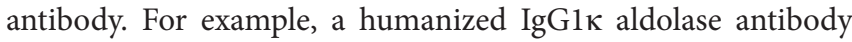
has been used as a scaffold for monovalent display of anti-VEGF and anti-Ang2 peptide pharmacophores to develop a monovalent bispecific COVX-241 (86). The bispecific COVX-241 inhibited VEGF-VEGFR2/Ang2-Tie2 interactions and further exhibited an improved efficacy against colon adenocarcinoma xenograft model as compared to the monospecific COVX-body (86).

Another methodology to develop bsAbs was proposed by Wranik et al. (87), which employed a common light chain and leucine zipper (LUZ-Y) (Figure 1N). They demonstrated 
heterodimer assembly by creating a point mutation and the addition of a leucine zipper at the heavy chain C-terminus (87). Further, K222A substitution was made in the hinge region to avoid Lys- $\mathrm{C}$ endopeptidase-mediated cleavage if used for removing leucine zipper through $\mathrm{C}$-terminal lysine of the $\mathrm{CH} 3$ domain. The light chain (VL-CL) was fused to the N-terminus of the heavy chain construct by a non-cleavable linker. However, the leucine zipper did not completely prevent homodimer formation, as an outcome of disproportionate expression in $\mathrm{CHO}$ cells most probably due to an incorrect DNA ratio during the transfection (87). Two armed LUZ-Y bispecific molecules hFceRI $\alpha \times$ hFc $\gamma$ RIIb showed desirable binding to respective targets and inhibited histamine release from $\mathrm{hFc}$ RI $\alpha / \mathrm{hFc} \mathrm{RIIb}^{+}$rat basophil leukemia cells when activated by IgE. Similarly, EGFR $\times$ HER3 bispecific LUZ-Y inhibited the growth of EGFR/HER3-dependent FaDu cells (87).

Bispecific IgG has also been assembled from a bacterial expression system. Half-IgG (one heavy and one light chain) molecule representing MET (hole mutant) and EGFR (knob mutant) specificities were expressed in bacterial cultures separately. The half-IgGs were purified by protein A affinity chromatography and analyzed to quantify monomeric form by size exclusion chromatography. Two half-IgGs were mixed in the presence of a reducing agent and subsequently oxidized to generate bsAb, which binds to the targets in a monovalent fashion (88). Similarly, a bacterial coculture of two strains expressing individual half-IgGs was shown to be the most rapid and efficient way to produce bsAbs (88). These bsAb molecules also inhibited MET $\times$ EGFR driven tumor growth (88).

In another effort, broadly neutralizing anti-HA1 (Ab-002) and HA2 (Ab-005) antibodies against influenza virus A were covalently linked by their C-termini. This methodology involved the fusion of a bacterial sortase recognition motif (LPETGG) via $\mathrm{G}_{4} \mathrm{~S}$ linker to the $\mathrm{C}$-terminus of the IgG heavy chain. Click chemistry in the form of either cyclooctyne (DIBAC) or azide was used in the presence of sortase to promote covalent association of the two antibody molecules (89). Such covalently linked antibodies remained stable for up to 3 weeks at $37^{\circ} \mathrm{C}$ and also retained the Fc effector functions. These bispecific covalently linked IgGs contributed to an increased breadth of HA binding and antiviral potency as compared to the monospecific molecules (89).

Further, the light chain pairing was also used to generate bsIg molecules ( $\kappa \lambda$-bodies) (Figure 10). This was achieved by coexpressing a single heavy chain with two light chains ( $\kappa$ and $\lambda$ ) through a single expression vector (63). It was presumed that $50 \%$ yield would be of $\kappa \lambda$ heterodimers. The strategy involved a threestep purification to separate (a) whole IgG fraction by protein A/ $\mathrm{CH} 1$ resin, (b) $\kappa$ light chain by kappa select resin, and (c) $\lambda$ light chain by lambda select resin. Fed-batch culture yielded $1.5 \mathrm{~g} / \mathrm{L}$ of total IgG with $41 \%$ being $\kappa \lambda$ heterodimer (63).

Smith et al. (58) used antibody isotype local chimeras to develop a bsAb that could trigger T cell-mediated B-cell killing. The rationale behind this approach was to exploit the differential protein A binding ability of antibody isotypes. It is known that IgG3 does not bind protein A and harbors a dipeptide Arg-Phe at the $\mathrm{CH} 3$ domain that corresponds to IgG1 H435 and Y436, respectively, while IgG1 can bind protein A with high affinity. Moreover, crystal structure of IgG1 in complex with protein A confirms that $\mathrm{H} 435$ is involved in interaction with protein $\mathrm{A}$ (90). Fc substitutions (H435R, Y436F) were created in anti-CD3 antibody to develop CD3 $\times$ CD20 bsAb using a common light chain. Such isotype local chimeras exhibited asymmetric binding to protein A, which was exploited for separation of heterodimers by a $\mathrm{pH}$ gradient (58). The yield of the bispecific CD $3 \times \mathrm{CD} 20$ IgG1 (REGN2280) was 43\%. The IgG4 isotype of CD3 $\times$ CD20 (REGN1979) exhibited $\mathrm{T}$ cell-mediated cytotoxicity against $\mathrm{CD}_{20}{ }^{+}$Raji lymphoma and inhibited the growth of Raji lymphoma cells in NOD SCID $\gamma$ (NSG) mice when injected along with the human PBMCs (58).

\section{bSAb FRAGMENTS FOR T CELL AND NK CELL ACTIVATION}

Besides the different formats of full-length bsAb design, significant effort has also been invested on bsAb fragment designs that lack Fc region or only contain some constant domains. The building blocks of bsAb fragments include nanobodies, human single-domain antibodies, scFvs, and Fabs (18). More than 25 bsAb fragment formats have been documented, and most formats currently under clinical trial for treatment of different tumors involve bridging immune effector $\mathrm{T}$ cell (CD3 as the antigen) toward tumor specific antigens (18).

Blinatumomab, the first bsAb fragment and second bispecific molecule approved for therapy, is a bispecific T-cell engager (BiTE) molecule (Figure 1P; Table 2 for clinical status) that is built from two scFvs linked in tandem with a short peptide linker $(64,91)$. Blinatumomab uses one arm to recognize CD19, which is highly expressed on B-cell acute lymphocytic leukemia (ALL), and the other arm to recruit CD3, which is expressed on T cells, and induces a T-cell-tumor cell contact and potent lysis of tumor cell $(64,91,92)$. Interestingly, the BiTE format of CD3 × CD19 bispecific antibody is superior to other formats including diabody (66) (Figure 1Q), tandem diabody (Tandab) $(67,68)$ (Figure 1R) and quadroma in terms of T cell-mediated tumor cell lysis (93). This finding highlights that the relative orientation and distance between the two scFvs may have significant impacts on how to bridge $\mathrm{T}$ cell and tumor cell into close contact so as to trigger $\mathrm{T}$ cell-mediated tumor cell lysis. Currently, several bispecific antibody fragments based on BiTE, Tandab, and dual-affinityretargeting (Figure 1S) (69) formats are under clinical trials involving CD3 and tumor related antigens $(18,94)$ (Table 2).

Effects of bsAb fragments capable of interacting with NK cells via CD16 have also been investigated. Gleason and coworkers demonstrated the enhanced efficacy of bscFv CD16 × CD19 and trispecific scFv CD16 $\times \mathrm{CD} 19 \times \mathrm{CD} 22$ constructs in targeting tumor cells by coengaging NK cell effector function (70). These molecules were termed as bispecific and trispecific killer cell engagers (BiKEs and TriKEs) (Figures 1T,U), respectively. Such molecules are constructed by linking specific binders together through a short linker derived from human muscle aldolase. Further, a BiKE construct against CD16 and CD33 has been shown to activate CD16 ${ }^{+} \mathrm{NK}$ cells to lyse CD33 ${ }^{+}$HL60 target cells (71). Recently, a TriKE construct with additional specificity against IL-15 induced enhanced NK cell cytotoxicity, degranulation, and cytokine production against $\mathrm{CD}^{+} 3^{+} \mathrm{HL} 60$ cells via 
increased NK cell proliferation and survival (72). Reusch et al. designed a Tandab-based anti-CD16A $\times$ CD30 bispecific tetravalent fragment and found that this format is better than normal monoclonal anti-CD30 IgG, optimized monoclonal anti-CD30 IgG for FcyR binding, and diabody (bispecific and bivalent antiCD16A and anti-CD30) formats in triggering NK cell lysis of Hodgkin lymphoma cells (CD30 as the antigen) $(95,96)$. This format of anti-CD16A $\times$ CD30 bispecific fragment (known as AFM13) is under phase-2 clinical trial (Table 2) for treatment of refractory or relapsed Hodgkin lymphoma patients (97).

\section{MONOMERIC Ig SCAFFOLDS}

Much work in the last 5 years has focused on engineering the IgG constant domains as scaffolds. The IgG-Fc region and isolated $\mathrm{CH}$ domains have shown promising virtues in terms of small size, antigen targeting, effector function, and serum half-life.

Soluble monomeric $\mathrm{Fc}(\mathrm{mFc})$ was developed by destabilizing the $\mathrm{CH} 3-\mathrm{CH} 3$ domain interface. A phage-displayed library was constructed with random mutations introduced within seven key residues known to be involved in $\mathrm{CH} 3$ domain homodimerization and selected against binding of protein $G$ first to enrich well-folded mutants and then against human FcRn (16). The selected clones were diverse in their $\mathrm{CH} 3$ domain, and monomer promoting mutations were identified (16). These variants with each containing six to seven mutations had considerably lower melting temperature but exhibited comparable stabilities and $\mathrm{pH}-$ dependent FcRn binding profiles to that of dimeric Fc (16). The experimental conceptualization was proved by $\mathrm{mFc} 67.3-\mathrm{m} 36 \mathrm{VH}$ fusion (Figure 1V) targeting HIV-1 envelope glycoprotein (ENV) and neutralization of viral isolates (16). Based on the identified $\mathrm{mFc}$ mutants, the same group (98) optimized $\mathrm{mFc}$ to generate mutants with fewer mutations and improved thermostability while maintaining similar $\mathrm{pH}$-dependent FcRn binding as that of wild-type $\mathrm{Fc}$ dimer. Interestingly, the new $\mathrm{mFc}$ mutants when expressed either in bacteria or mammalian cells all showed selective binding to only Fc $\gamma$ RI but not to other receptors including FcyRIIa, Fc $\gamma$ RIIb, FcyRIIIa, and C1q (98). This selectivity attractively made the $\mathrm{mFc}$ mutant as a potential carrier to treat chronic inflammatory diseases where inflammatory macrophages showed increased expression of FcyRI (98-103). In addition, this selectivity also excluded unwanted cytotoxicities such as ADCC from FcyRIIIa and CDC from C1q (98).

In another strategy to keep $\mathrm{Fc}$ in a monomeric form, asparagine-linked glycan structures were engineered into the $\mathrm{CH} 3-\mathrm{CH} 3$ interface of IgG1 Fc lacking the hinge (104). A mutant incorporating $\mathrm{N}$-glycosylation sites (asparagine at positions 364 and 407) yielded a stable, soluble, and $\mathrm{mFc}$ scaffold with wild-type-like FcRn binding activity, which suggests that N-glycosylation promotes functional monomeric state and improves the biophysical characteristics (104).

Smaller scaffolds like $\mathrm{CH} 2$ domains also possess interesting properties like a properly folded structure, conformational flexibility, lesser propensity to dimerize, and associated FcRn/C1q binding functions, which can have therapeutic benefits $(103,105)$. A CH2 domain variant (m01) harboring disulfide bond mutations (L12C and K104C) was found to exist solely as a monomer and remained thermally more stable than native counterparts (105). Further, 50\% of monomeric $\mathrm{CH} 2$ unfolded at a urea concentration of $6.8 \mathrm{M}$ as compared to $4.8 \mathrm{M}$ for the wild-type $\mathrm{CH} 2$ (105). The biophysical attributes of the $\mathrm{CH} 2$ domain (m01) were further optimized by developing a shorter version where the unstructured random coil at the $\mathrm{N}$-terminus was shortened by seven residues (m01s) (106). This strategy increased the melting temperature of $\mathrm{CH} 2$ isolate up to $82.6^{\circ} \mathrm{C}$, enhanced stability in serum and mediated stronger binding to soluble FcRn (106). Similarly, a structure-guided design allowed the engineering of an IgG1-CH3 FcRn recognition motif into the $\mathrm{CH} 2$ scaffold to impart enhanced $\mathrm{pH}$-dependent $\mathrm{FcRn}$ binding, prolongation of serum half-life, and epithelial transcytosis in comparison to parent $\mathrm{CH} 2$ isolate (m01s) (107).

Antigen recognition activity was engineered in $\mathrm{CH} 2$ scaffolds carrying mutations in the $\mathrm{BC}$ and FG loops by selecting against the HIV-1 envelope glycoprotein (gp120)-CD4 complex (15), which yielded $\mathrm{CH} 2$ fragments bearing the same $\mathrm{BC}$ but different FG loops, suggesting the importance of the latter in such interactions. One such isolate (m1a1) specifically recognized a highly conserved CD4i epitope on the HIV-1 gp120 protein and neutralized HIV-1 isolates in a cell based pseudovirus assay (15). In another approach, a randomly selected $\mathrm{VH}$ domain targeting the HIV-1 gp41 protein was grafted into the BC/FG loops of "m01s" without affecting the flanking regions to develop antigen targeting $\mathrm{CH} 2$ domains (m2a1) (108). This domain bound to sp62 peptide of HIV-1 envelope membrane-proximal external region, neutralized HIV-1 isolates, and showed $\mathrm{pH}$-dependent FcRn interaction (108).

Initial success with the $\mathrm{mFc}$ and $\mathrm{CH} 2$ domains prompted the development of a monomeric $\mathrm{CH} 3$ (mCH3) scaffold $(103,109)$. The seven contact residues of the $\mathrm{CH} 3$ domain from the previously reported $\mathrm{mFc}$ molecules (16) were mutated, and a combination of mutations was found to be required for $\mathrm{CH} 3$ monomer to exist (109). These mutations were responsible for stronger intermolecular hydrophobic interactions, which resulted in an intact, folded and thermally stable $\mathrm{CH} 3$ monomer (109). The $\mathrm{mCH} 3$ scaffold exhibited significant binding to $\mathrm{FcRn}$ and protein $\mathrm{G}$ (109). Furthermore, $\mathrm{mCH} 3$ fused to a VH domain of an HIV-1 targeting antibody (m36.4) showed satisfactory stability, viral neutralization, and $\mathrm{pH}$-dependent FcRn binding (109). A comparative analysis between the dimeric and monomeric scaffolds has demonstrated increased solubility, comparable serum stability, and higher $\mathrm{pH}$-dependent FcRn binding by monomers (103). These properties make antibody scaffolds promising potential therapeutic candidates.

\section{Fc ANTIGEN-BINDING FRAGMENT}

The Fc has also been developed as an antigen-binding domain "Fcab" (Figure 1W) by imparting specificity against antigens through yeast surface display (110). The AB and EF loops of IgG1-CH3 domain were randomly mutagenized, cloned into a yeast surface display vector, and selected against HER2/neu extracellular domain (ECD) for two rounds. The selected binders were again randomized in the $\mathrm{AB}$ loop and selected on HER2/ neu ECD. One of the isolated Fcab molecules (H10-03-6) showed 
specificity for binding to HER2, retained binding to Fc $\gamma$ RI/protein $\mathrm{A}$, and exhibited an in vivo pharmacokinetics profile similar to the native human Fc (110). Post-affinity maturation, Fcab exhibited $\sim 10$-fold enhanced binding to the antigen as compared to the parental molecule and elicited NK cell-mediated cytotoxicity in vitro against the breast cancer cell line Calu-3, but the potency was 20 -fold weaker than that of Herceptin (110).

Introducing antigen-binding ability into the Fc fragment could compromise stability, and therefore, additional disulfide bonds were engineered within the $\mathrm{CH} 3$ domain to provide increased stability (111). Further, these mutations did not affect $\mathrm{pH}$-dependent FcRn binding, which suggests the correct folding of the engineered Fc fragments (111). Similarly, immune modulating activity of Fcab was demonstrated using a HER2 targeting Fcab (HAF3-4), bearing CD16a modulating mutations (111). Both mutants showed binding to the recombinant or cell surface expressed HER2 and had an expected CD16a modulating behavior which correlated with the ADCC potency (111). Later, Woisetschlager and coworkers (112) showed the in vivo tumor reduction efficacy of anti-HER2 Fcab (H10-03-6) by simultaneous engagement of the HER2/CD16a and the involvement of ADCC (112).

Since antigen-antibody interaction at an acidic $\mathrm{pH}$ can negatively affect drug pharmacokinetics, anti-HER2 Fcab (H10-03-6) variants with weaker binding at $\mathrm{pH} 6.0$ were developed (113). The residues in the $\mathrm{AB}$ and $\mathrm{EF}$ loops were randomized and selected against HER2-ECD alternately at $\mathrm{pH} 7.4$ and 6.0 using yeast display. The isolated binders exhibited lower affinity at an acidic $\mathrm{pH}$ and similarly engaged $\mathrm{HER} 2^{+}$cells in a $\mathrm{pH}$-dependant manner (113). A year later, Leung et al. (114) developed Fcab that could degrade HER2 and induce apoptosis. The AB and EF loop residues of IgG-Fc were randomly mutagenized and selected via yeast display for binding to HER2-ECD. After affinity maturation, the candidate Fcab (FS102) exhibited an affinity for HER2-ECD that was equivalent to that of pertuzumab and trastuzumab and an extended serum half-life comparable to the native Fc (114). Further, $\mathrm{EC}_{50}$ values of 1.1 and $3.3 \mathrm{nM}$ were observed against SKBr3 and HCC1954 breast cancer cells, respectively, and a complete tumor regression was shown using $\mathrm{HER} 2^{+}$patient-derived colorectal/gastric cancer xenografts (114). This effect correlated with caspase 3/7 activation in SKBr3 cells in a dose-dependent manner indicating the induction of tumor cell apoptosis (114).

\section{CHALLENGES IN CLINICAL DEVELOPMENT OF bsAbs AND FRAGMENTS}

Smaller antibody fragments (nanobody, human single-domain $\mathrm{Ab}, \mathrm{scFv}$, or Fab) and bsAb fragments offer a number of advantages over full-length IgG, including ability to penetrate tissue, cost effective and facile manufacturing methods, and high yields $(23,115)$. However, their small size leads to a shorter serum halflife, lesser tissue retention, and rapid clearance from the blood through kidneys. This is true for blinatumomab, which has a serum half-life of around $2 \mathrm{~h}$ while the serum half-life of fulllength IgG1 is around 2-3 weeks. Thus, patients need a regimen of at least 3-cycle treatment with each cycle consisting of continuous infusion for 4 weeks in a cycle of 6 weeks (116). On the other hand, the fast clearance of small size bsAb fragments may be desirable in imaging and radioimmunotherapy $(117,118)$.

Specific approaches can be used to increase the longevity of small bsAb fragments in blood and tissue by (1) fusion of the Fc region of IgG molecules or human serum albumin to prolong the serum half-life. These fusions not only increase molecular size of bsAb fragments and therefore protect them from being excreted out of the body but also mediate binding to the FcRn expressed on the endothelial cells to enter IgG serum stabilization pathway (25, 119-121); (2) multimerization of antibody fragments to increase the molecular size for stabilizing concentration in blood and enhancing the valency of antigen binding $(120,122)$. The multimerization approach, however, runs a risk of imparting heterogeneity to the molecule and can also lead to undesirable effects by crosslinking of the target receptor (120); and (3) linking of a hydrophobic molecule like polyethylene glycol, a clinically proven technology for serum half-life extension (120, 123). Besides, other polymers like polysialic acid, $N$-(2-hydroxypropyl) methacrylamide, and dextran can also provide protection to the small antibody fragments $(25,120)$.

Currently, there are more than 60 bsAb formats (18). Of note, the success story of blinatumomab in the format of BiTE, but not in other formats including diabody, Tandab, and quadroma indicates that bispecific molecule design has to consider more than one format from the beginning (93). Moreover, expression and purification of these variable formats require tailored procedures based on each design. This may pose a great challenge in developing bispecific molecules. Table 1 summarizes relevant information from available literatures.

\section{FINAL REMARKS}

Considerable progress has been made in the development of bispecific molecules based on different scaffolds in recent years. Much of this understanding has made it possible to enter an era of bispecific clinical development with two such molecules (catumaxomab and blinatumomab) having been approved for clinical use in humans (18). The field of bsAbs has been evolutionary and revolutionary, which is reflected in our ability to obtain $100 \%$ pure heterodimers, the complete evasion of heavy and light chain mispairing, fairly standardized production/purification/ analytical methods and, importantly, clear ideas of their potential applications.

The full-length mAbs have relatively poor tissue penetration ability. In contrast, smaller antibody fragments like BiTE, BiKE, and TriKE can effectively penetrate tumor tissue and efficiently recruit and activate immune effector cells to lyse tumor cells $(23,70,93,115)$. Besides, the recent success in delivering a bsIg across the blood-brain barrier by targeting transferrin receptor and $\beta$-secretase to reduce brain amyloid- $\beta$ in non-human primate model may open the era of specific antibody brain delivery and treatment of neurodegenerative diseases (124). In another possibility, combining non-antibody small fragments such as lambody, affibody, and aptamer with current antibody scaffolds may expand the treatment arsenal of bispecific molecules. 
Moreover, monomeric Ig domain scaffold and Fcab are potent new formats to target difficult to reach sites in the body and to add additional antigen specificity along with enhanced stability, effector function, and extended serum half-life. These properties make them suitable for clinical validation.

In the future, bispecific molecules based on various scaffolds will represent an indispensable class of therapeutic options to treat a variety of clinical indications. However, efforts to improve production and purification on an industrial scale must continue to ensure harvesting of the full benefits of these entities.

\section{REFERENCES}

1. Ecker DM, Jones SD, Levine HL. The therapeutic monoclonal antibody market. MAbs (2015) 7:9-14. doi:10.4161/19420862.2015.989042

2. Henry HC. Therapeutic monoclonal antibodies approved by FDA in 2015 . MOJ Immunol (2016) 3:00087. doi:10.15406/moji.2016.03.00087

3. Schroeder HW Jr, Cavacini L. Structure and function of immunoglobulins. J Allergy Clin Immunol (2010) 125:S41-52. doi:10.1016/j.jaci.2009.09.046

4. Igawa T, Tsunoda H, Kuramochi T, Sampei Z, Ishii S, Hattori K. Engineering the variable region of therapeutic IgG antibodies. MAbs (2011) 3:243-52. doi:10.4161/mabs.3.3.15234

5. Duncan AR, Winter G. The binding site for Clq on IgG. Nature (1988) 332:738-40. doi:10.1038/332738a0

6. Ghetie V, Ward ES. Multiple roles for the major histocompatibility complex class I-related receptor FcRn. Annu Rev Immunol (2000) 18:739-66. doi:10.1146/annurev.immunol.18.1.739

7. Idusogie EE, Presta LG, Gazzano-Santoro H, Totpal K, Wong PY, Ultsch $\mathrm{M}$, et al. Mapping of the $\mathrm{Clq}$ binding site on rituxan, a chimeric antibody with a human IgG1 Fc. JImmunol (2000) 164:4178-84. doi:10.4049/ jimmunol.164.8.4178

8. Jefferis R, Lund J, Pound JD. IgG-Fc-mediated effector functions: molecular definition of interaction sites for effector ligands and the role of glycosylation. Immunol Rev (1998) 163:59-76. doi:10.1111/j.1600-065X.1998.tb01188.x

9. Jung ST, Kang TH, Kelton W, Georgiou G. Bypassing glycosylation: engineering aglycosylated full-length IgG antibodies for human therapy. Curr Opin Biotechnol (2011) 22:858-67. doi:10.1016/j.copbio.2011.03.002

10. Kim JK, Tsen MF, Ghetie V, Ward ES. Localization of the site of the murine IgG1 molecule that is involved in binding to the murine intestinal Fc receptor. Eur J Immunol (1994) 24:2429-34. doi:10.1002/eji.1830241025

11. Lund J, Winter G, Jones PT, Pound JD, Tanaka T, Walker MR, et al. Human Fc gamma RI and Fc gamma RII interact with distinct but overlapping sites on human IgG. J Immunol (1991) 147:2657-62.

12. Park HI, Yoon HW, Jung ST. The highly evolvable antibody Fc domain. Trends Biotechnol (2016) 16:30024-5. doi:10.1016/j.tibtech.2016.04.005

13. Sondermann P, Szymkowski DE. Harnessing Fc receptor biology in the design of therapeutic antibodies. Curr Opin Immunol (2016) 40:78-87. doi:10.1016/j.coi.2016.03.005

14. Saxena $\mathrm{A}, \mathrm{Wu} \mathrm{D}$. Advances in therapeutic Fc engineering - modulation of IgG-Associated effector functions and serum half-life. Front Immunol (2016) 7:580. doi:10.3389/fimmu.2016.00580

15. Xiao X, Feng $\mathrm{Y}, \mathrm{Vu} \mathrm{BK}$, Ishima R, Dimitrov DS. A large library based on a novel (CH2) scaffold: identification of HIV-1 inhibitors. Biochem Biophys Res Commun (2009) 387:387-92. doi:10.1016/j.bbrc.2009.07.044

16. Ying T, Chen W, Gong R, Feng Y, Dimitrov DS. Soluble monomeric IgG1 Fc. J Biol Chem (2012) 287:19399-408. doi:10.1074/jbc.M112.368647

17. Kontermann RE, Brinkmann U. Bispecific antibodies. Drug Discov Today (2015) 20:838-47. doi:10.1016/j.drudis.2015.02.008

18. Spiess C, Zhai Q, Carter PJ. Alternative molecular formats and therapeutic applications for bispecific antibodies. Mol Immunol (2015) 67:95-106. doi:10.1016/j.molimm.2015.01.003

19. Castoldi R, Jucknischke U, Pradel LP, Arnold E, Klein C, Scheiblich S, et al. Molecular characterization of novel trispecific ErbB-cMet-IGF1R antibodies and their antigen-binding properties. Protein Eng Des Sel (2012) 25:551-9. doi:10.1093/protein/gzs048

\section{AUTHOR CONTRIBUTIONS}

DW conceived the topic; DW, HL, and AS wrote the manuscript; HL and AS contributed equally in writing the manuscript; DW and SS revised the manuscript.

\section{FUNDING}

This work was supported by National Natural Science Foundation of China (Grant No.: 81572698) to DW.

20. Nuñez-Prado N, Compte M, Harwood S, Álvarez-Méndez A, Lykkemark S, Sanz L, et al. The coming of age of engineered multivalent antibodies. Drug Discov Today (2015) 20:588-94. doi:10.1016/j.drudis.2015.02.013

21. Köhler G, Milstein C. Continuous cultures of fused cells secreting antibody of predefined specificity. Nature (1975) 256:495-7. doi:10.1038/256495a0

22. Milstein C, Cuello AC. Hybrid hybridomas and their use in immunohistochemistry. Nature (1983) 305:537-40. doi:10.1038/305537a0

23. Chames P, Van Regenmortel M, Weiss E, Baty D. Therapeutic antibodies: successes, limitations and hopes for the future. Br J Pharmacol (2009) 157:220-33. doi:10.1111/j.1476-5381.2009.00190.x

24. Heiss MM, Murawa P, Koralewski P, Kutarska E, Kolesnik OO, Ivanchenko $\mathrm{VV}$, et al. The trifunctional antibody catumaxomab for the treatment of malignant ascites due to epithelial cancer: results of a prospective randomized phase II/III trial. Int J Cancer (2010) 127:2209-21. doi:10.1002/ ijc. 25423

25. Fan G, Wang Z, Hao M, Li J. Bispecific antibodies and their applications. J Hematol Oncol (2015) 8:130. doi:10.1186/s13045-015-0227-0

26. Lindhofer H, Mocikat R, Steipe B, Thierfelder S. Preferential speciesrestricted heavy/light chain pairing in rat/mouse quadromas. Implications for a single-step purification of bispecific antibodies. JImmunol (1995) 155:219-25.

27. Atwell S, Ridgway JB, Wells JA, Carter P. Stable heterodimers from remodeling the domain interface of a homodimer using a phage display library. $J \mathrm{Mol}$ Biol (1997) 270:26-35. doi:10.1006/jmbi.1997.1116

28. Merchant AM, Zhu Z, Yuan JQ, Goddard A, Adams CW, Presta LG, et al. An efficient route to human bispecific IgG. Nat Biotechnol (1998) 16:677-81. doi:10.1038/nbt0798-677

29. Ridgway JB, Presta LG, Carter P. 'Knobs-into-holes' engineering of antibody CH3 domains for heavy chain heterodimerization. Protein Eng (1996) 9:617-21. doi:10.1093/protein/9.7.617

30. Hamers-Casterman C, Atarhouch T, Muyldermans S, Robinson G, Hamers C, Songa EB, et al. Naturally occurring antibodies devoid of light chains. Nature (1993) 363:446-8. doi:10.1038/363446a0

31. Muyldermans S. Nanobodies: natural single-domain antibodies. Annu Rev Biochem (2013) 82:775-97. doi:10.1146/annurev-biochem-063011-092449

32. Wolfson W. Ablynx makes nanobodies from llama bodies. Chem Biol (2006) 13:1243-4. doi:10.1016/j.chembiol.2006.12.003

33. Coppieters K, Dreier T, Silence K, de Haard H, Lauwereys M, Casteels P, et al. Formatted anti-tumor necrosis factor alpha $\mathrm{VHH}$ proteins derived from camelids show superior potency and targeting to inflamed joints in a murine model of collagen-induced arthritis. Arthritis Rheum (2006) 54:1856-66. doi:10.1002/art.21827

34. Davies J, Riechmann L. Antibody VH domains as small recognition units. Biotechnology (N Y) (1995) 13:475-9. doi:10.1038/nbt0595-475

35. van den Beucken T, van Neer N, Sablon E, Desmet J, Celis L, Hoogenboom $\mathrm{HR}$, et al. Building novel binding ligands to B7.1 and B7.2 based on human antibody single variable light chain domains. J Mol Biol (2001) 310:591-601. doi:10.1006/jmbi.2001.4703

36. Barthelemy PA, Raab H, Appleton BA, Bond CJ, Wu P, Wiesmann C, et al. Comprehensive analysis of the factors contributing to the stability and solubility of autonomous human VH domains. J Biol Chem (2008) 283:3639-54. doi:10.1074/jbc.M708536200

37. De Bernardis F, Liu H, O’Mahony R, La Valle R, Bartollino S, Sandini S, et al. Human domain antibodies against virulence traits of Candida albicans inhibit 
fungus adherence to vaginal epithelium and protect against experimental vaginal candidiasis. J Infect Dis (2007) 195:149-57. doi:10.1086/509891

38. Bird RE, Hardman KD, Jacobson JW, Johnson S, Kaufman BM, Lee SM, et al. Single-chain antigen-binding proteins. Science (1988) 242:423-6. doi:10.1126/science.3140379

39. Huston JS, Levinson D, Mudgett-Hunter M, Tai MS, Novotny J, Margolies $\mathrm{MN}$, et al. Protein engineering of antibody binding sites: recovery of specific activity in an anti-digoxin single-chain Fv analogue produced in Escherichia coli. Proc Natl Acad Sci U S A (1988) 85:5879-83. doi:10.1073/pnas.85.16.5879

40. Hong X, Ma MZ, Gildersleeve JC, Chowdhury S, Barchi JJ Jr, Mariuzza RA, et al. Sugar binding proteins from fish: selection of high affinity "lambodies" that recognize biomedically relevant glycans. ACS Chem Biol (2013) 8:152-60. doi:10.1021/cb300399s

41. Hansson M, Ringdahl J, Robert A, Power U, Goetsch L, Nguyen TN, et al. An in vitro selected binding protein (affibody) shows conformationdependent recognition of the respiratory syncytial virus (RSV) G protein. Immunotechnology (1999) 4:237-52. doi:10.1016/S1380-2933(98)00026-8

42. Pestourie C, Tavitian B, Duconge F. Aptamers against extracellular targets for in vivo applications. Biochimie (2005) 87:921-30. doi:10.1016/ j.biochi.2005.04.013

43. Nimjee SM, Rusconi CP, Sullenger BA. Aptamers: an emerging class of therapeutics. Annu Rev Med (2005) 56:555-83. doi:10.1146/annurev. med.56.062904.144915

44. Ronnmark J, Hansson M, Nguyen T, Uhlen M, Robert A, Stahl S, et al. Construction and characterization of affibody-Fc chimeras produced in Escherichia coli. JImmunol Methods (2002) 261:199-211. doi:10.1016/ S0022-1759(01)00563-4

45. Dickgiesser S, Rasche N, Nasu D, Middel S, Horner S, Avrutina O, et al. Selfassembled hybrid aptamer-Fc conjugates for targeted delivery: a modular chemoenzymatic approach. ACS Chem Biol (2015) 10:2158-65. doi:10.1021/ acschembio. 5 b00315

46. Moldenhauer G. Bispecific antibodies from hybrid hybridoma. In: Kontermann RE, editor. Bispecific Antibodies. Berlin, Heidelberg: Springer (2011). p. 29-46.

47. Schaefer W, Regula JT, Bähner M, Schanzer J, Croasdale R, Dürr H, et al. Immunoglobulin domain crossover as a generic approach for the production of bispecific IgG antibodies. Proc Natl Acad Sci U S A (2011) 108:11187-92. doi:10.1073/pnas. 1019002108

48. Schanzer JM, Wartha K, Croasdale R, Moser S, Künkele KP, Ries C, et al. A novel glycoengineered bispecific antibody format for targeted inhibition of epidermal growth factor receptor (EGFR) and insulin-like growth factor receptor type I (IGF-1R) demonstrating unique molecular properties. J Biol Chem (2014) 289:18693-706. doi:10.1074/jbc.M113.528109

49. Metz S, Panke C, Haas AK, Schanzer J, Lau W, Croasdale R, et al. Bispecific antibody derivatives with restricted binding functionalities that are activated by proteolytic processing. Protein Eng Des Sel (2012) 25:571-80. doi:10.1093/ protein/gzs064

50. Elliott JM, Ultsch M, Lee J, Tong R, Takeda K, Spiess C, et al. Antiparallel conformation of knob and hole aglycosylated half-antibody homodimers is mediated by a $\mathrm{CH} 2-\mathrm{CH} 3$ hydrophobic interaction. J Mol Biol (2014) 426:1947-57. doi:10.1016/j.jmb.2014.02.015

51. Xu Y, Lee J, Tran C, Heibeck TH, Wang WD, Yang J, et al. Production of bispecific antibodies in "knobs-into-holes" using a cell-free expression system. MAbs (2015) 1:231-42. doi:10.4161/19420862.2015.989013

52. Mazor Y, Oganesyan V, Yang C, Hansen A, Wang J, Liu H, et al. Improving target cell specificity using a novel monovalent bispecific IgG design. MAbs (2015) 7:377-89. doi:10.1080/19420862.2015.1007816

53. Zhao L, Xie F, Tong X, Li H, Chen Y, Qian W, et al. Combating nonHodgkin lymphoma by targeting both CD20 and HLA-DR through CD20243 CrossMab. MAbs (2014) 3:740-8. doi:10.4161/mabs.28613

54. Moore GL, Bautista C, Pong E, Nguyen DH, Jacinto J, Eivazi A, et al. A novel bispecific antibody format enables simultaneous bivalent and monovalent co-engagement of distinct target antigens. MAbs (2011) 3:546-57. doi:10.4161/mabs.3.6.18123

55. Strop P, Ho WH, Boustany LM, Abdiche YN, Lindquist KC, Farias SE, et al. Generating bispecific human IgG1 and IgG2 antibodies from any antibody pair. J Mol Biol (2012) 420:204-19. doi:10.1016/j.jmb.2012.04.020
56. Labrijn AF, Meesters JI, de Goeij BE, van den Bremer ET, Neijssen J, van Kampen MD, et al. Efficient generation of stable bispecific IgG1 by controlled Fab-arm exchange. Proc Natl Acad Sci U S A (2013) 110:5145-50. doi:10.1073/ pnas. 1220145110

57. Liu Z, Leng EC, Gunasekaran K, Pentony M, Shen M, Howard M, et al. A novel antibody engineering strategy for making monovalent bispecific heterodimeric IgG antibodies by electrostatic steering mechanism. J Biol Chem (2015) 290:7535-62. doi:10.1074/jbc.M114.620260

58. Smith EJ, Olson K, Haber LJ, Varghese B, Duramad P, Tustian AD, et al. A novel, native-format bispecific antibody triggering T-cell killing of B-cells is robustly active in mouse tumor models and cynomolgus monkeys. Sci Rep (2015) 5:17943. doi:10.1038/srep17943

59. Gunasekaran K, Pentony M, Shen M, Garrett L, Forte C, Woodward A, et al. Enhancing antibody Fc heterodimer formation through electrostatic steering effects: applications to bispecific molecules and monovalent IgG. J Biol Chem (2010) 285:19637-46. doi:10.1074/jbc.M110.117382

60. Choi HJ, Kim YJ, Lee S, Kim YS. A heterodimeric Fc-based bispecific antibody simultaneously targeting VEGFR-2 and Met exhibits potent antitumor activity. Mol Cancer Ther (2013) 12:2748-59. doi:10.1158/1535-7163. MCT-13-0628

61. Choi HJ, Kim YJ, Choi DK, Kim YS. Engineering of immunoglobulin Fc heterodimers using yeast surface-displayed combinatorial Fc library screening. PLoS One (2015) 10:e0145349. doi:10.1371/journal.pone.0145349

62. Von Kreudenstein TS, Escobar-Carbrera E, Lario PI, D’Angelo I, Brault K, Kelly J, et al. Improving biophysical properties of a bispecific antibody scaffold to aid developability: quality by molecular design. MAbs (2013) 5:646-54. doi:10.4161/mabs.25632

63. Fischer N, Elson G, Magistrelli G, Dheilly E, Fouque N, Laurendon A, et al. Exploiting light chains for the scalable generation and platform purification of native human bispecific IgG. Nat Commun (2015) 6:6113. doi:10.1038/ ncomms7113

64. Löffler A, Kufer P, Lutterbüse R, Zettl F, Daniel PT, Schwenkenbecher JM, et al. A recombinant bispecific single-chain antibody, CD19 x CD3, induces rapid and high lymphoma-directed cytotoxicity by unstimulated T lymphocytes. Blood (2000) 95:2098-103.

65. Mack M, Riethmüller G, Kufer P. A small bispecific antibody construct expressed as a functional single-chain molecule with high tumor cell cytotoxicity. Proc Natl Acad Sci U S A (1995) 92:7021-5. doi:10.1073/ pnas.92.15.7021

66. Holliger P, Prospero T, Winter G. "Diabodies": small bivalent and bispecific antibody fragments. Proc Natl Acad Sci U S A (1993) 90:6444-8. doi:10.1073/ pnas.90.14.6444

67. Arndt MA, Krauss J, Kipriyanov SM, Pfreundschuh M, Little M. A bispecific diabody that mediates natural killer cell cytotoxicity against xenotransplantated human Hodgkin's tumors. Blood (1999) 94:2562-8.

68. Kipriyanov SM, Moldenhauer G, Schuhmacher J, Cochlovius B, Von der Lieth CW, Matys ER, et al. Bispecific tandem diabody for tumor therapy with improved antigen binding and pharmacokinetics. J Mol Biol (1999) 293:41-56. doi:10.1006/jmbi.1999.3156

69. Johnson S, Burke S, Huang L, Gorlatov S, Li H, Wang W, et al. Effector cell recruitment with novel Fv-based dual-affinity re-targeting protein leads to potent tumor cytolysis and in vivo B-cell depletion. J Mol Biol (2010) 399:436-49. doi:10.1016/j.jmb.2010.04.001

70. Gleason MK, Verneris MR, Todhunter DA, Zhang B, McCullar V, Zhou SX, et al. Bispecific and trispecific killer cell engagers directly activate human NK cells through CD16 signaling and induce cytotoxicity and cytokine production. Mol Cancer Ther (2012) 11:2674-84. doi:10.1158/1535-7163. MCT-12-0692

71. Wiernik A, Foley B, Zhang B, Verneris MR, Warlick E, Gleason MK, et al. Targeting natural killer cells to acute myeloid leukemia in vitro with a CD16 x 33 bispecific killer cell engager and ADAM17 inhibition. Clin Cancer Res (2013) 19:3844-55. doi:10.1158/1078-0432.CCR-13-0505

72. Vallera DA, Felices M, McElmurry R, McCullar V, Zhou X, Schmohl JU, et al. IL15 trispecific killer engagers (TriKE) make natural killer cells specific to $\mathrm{CD} 33+$ targets while also inducing persistence, in vivo expansion, and enhanced function. Clin Cancer Res (2016) 22:3440-50. doi:10.1158/10780432.CCR-15-2710 
73. Song MK, Oh MS, Lee JH, Lee JN, Chung JH, Park SG, et al. Light chain of natural antibody plays a dominant role in protein antigen binding. Biochem Biophys Res Commun (2000) 268:390-4. doi:10.1006/bbrc.2000.2134

74. Persson H, Ye W, Wernimont A, Adams JJ, Koide A, Koide S, et al. CDR-H3 diversity is not required for antigen recognition by synthetic antibodies. J Mol Biol (2013) 425:803-11. doi:10.1016/j.jmb.2012.11.037

75. Lewis SM, Wu X, Pustilnik A, Sereno A, Huang F, Rick HL, et al. Generation of bispecific IgG antibodies by structure-based design of an orthogonal Fab interface. Nat Biotechnol (2014) 32:191-8. doi:10.1038/nbt.2797

76. Leaver-Fay A, Froning KJ, Atwell S, Aldaz H, Pustilnik A, Lu F, et al. Computationally designed bispecific antibodies using negative state repertoires. Structure (2016) 24:641-51. doi:10.1016/j.str.2016.02.013

77. Muller KM, Arndt KM, Strittmatter W, Pluckthun A. The first constant domain $(\mathrm{C}(\mathrm{H}) 1$ and $\mathrm{C}(\mathrm{L}))$ of an antibody used as heterodimerization domain for bispecific miniantibodies. FEBS Lett (1998) 422:259-64. doi:10.1016/ S0014-5793(98)00021-0

78. Allaway GP, Davis-Bruno KL, Beaudry GA, Garcia EB, Wong EL, Ryder AM, et al. Expression and characterization of CD4-IgG2, a novel heterotetramer that neutralizes primary HIV type 1 isolates. AIDS Res Hum Retroviruses (1995) 11:533-9. doi:10.1089/aid.1995.11.533

79. Schoonjans R, Willems A, Schoonooghe S, Fiers W, Grooten J, Mertens N. Fab chains as an efficient heterodimerization scaffold for the production of recombinant bispecific and trispecific antibody derivatives. J Immunol (2000) 165:7050-7. doi:10.4049/jimmunol.165.12.7050

80. Rothlisberger D, Honegger A, Pluckthun A. Domain interactions in the Fab fragment: a comparative evaluation of the single-chain Fv and Fab format engineered with variable domains of different stability. J Mol Biol (2005) 347:773-89. doi:10.1016/j.jmb.2005.01.053

81. Chen W, Bardhi A, Feng Y, Wang Y, Qi Q, Li W, et al. Improving the CH1-CK heterodimerization and pharmacokinetics of $4 \mathrm{Dm} 2 \mathrm{~m}$, a novel potent CD4antibody fusion protein against HIV-1. MAbs (2016) 8:761-74. doi:10.1080/ 19420862.2016.1160180

82. Chen W, Feng Y, Prabakaran P, Ying T, Wang Y, Sun J, et al. Exceptionally potent and broadly cross-reactive, bispecific multivalent HIV-1 inhibitors based on single human CD4 and antibody domains. J Virol (2014) 88:112539. doi:10.1128/JVI.02566-13

83. Chen W, Feng Y, Gong R, Zhu Z, Wang Y, Zhao Q, et al. Engineered single human CD4 domains as potent HIV-1 inhibitors and components of vaccine immunogens. J Virol (2011) 85:9395-405. doi:10.1128/JVI.05119-11

84. Chen W, Xiao X, Wang Y, Zhu Z, Dimitrov DS. Bifunctional fusion proteins of the human engineered antibody domain m36 with human soluble CD4 are potent inhibitors of diverse HIV-1 isolates. Antiviral Res (2010) 88:107-15. doi:10.1016/j.antiviral.2010.08.004

85. Davis JH, Aperlo C, Li Y, Kurosawa E, Lan Y, Lo KM, et al. SEEDbodies: fusion proteins based on strand-exchange engineered domain (SEED) $\mathrm{CH} 3$ heterodimers in an Fc analogue platform for asymmetric binders or immunofusions and bispecific antibodies. Protein Eng Des Sel (2010) 23:195-202. doi:10.1093/protein/gzp094

86. Doppalapudi VR, Huang J, Liu D, Jin P, Liu B, Li L, et al. Chemical generation of bispecific antibodies. Proc Natl Acad Sci U S A (2010) 107:22611-6. doi:10.1073/pnas.1016478108

87. Wranik BJ, Christensen EL, Schaefer G, Jackman JK, Vendel AC, Eaton D. LUZ-Y, a novel platform for the mammalian cell production of full-length IgG-bispecific antibodies. J Biol Chem (2012) 287:43331-9. doi:10.1074/jbc. M112.397869

88. Spiess C, Merchant M, Huang A, Zheng Z, Yang NY, Peng J, et al. Bispecific antibodies with natural architecture produced by co-culture of bacteria expressing two distinct half-antibodies. Nat Biotechnol (2013) 31:753-8. doi:10.1038/nbt.2621

89. Wagner K, Kwakkenbos MJ, Claassen YB, Maijoor K, Böhne M, van der Sluijs KF, et al. Bispecific antibody generated with sortase and click chemistry has broad antiinfluenza virus activity. Proc Natl Acad Sci U S A (2014) 111:16820-5. doi:10.1073/pnas.1408605111

90. Deisenhofer J. Crystallographic refinement and atomic models of a human Fc fragment and its complex with fragment B of protein A from Staphylococcus aureus at 2.9- and 2.8-A resolution. Biochemistry (1981) 20:2361-70. doi:10.1021/bi00512a001

91. Topp MS, Gökbuget N, Stein AS, Zugmaier G, O’Brien S, Bargou RC, et al. Safety and activity of blinatumomab for adult patients with relapsed or refractory B-precursor acute lymphoblastic leukaemia: a multicentre, single-arm, phase 2 study. Lancet Oncol (2015) 16:57-66. doi:10.1016/ S1470-2045(14)71170-2

92. Wolf E, Hofmeister R, Kufer P, Schlereth B, Baeuerle PA. BiTEs: bispecific antibody constructs with unique anti-tumor activity. Drug Discov Today (2005) 10:1237-44. doi:10.1016/S1359-6446(05)03554-3

93. Mølhøj M, Crommer S, Brischwein K, Rau D, Sriskandarajah M, Hoffmann P, et al. CD19-/CD3-bispecific antibody of the BiTE class is far superior to tandem diabody with respect to redirected tumor cell lysis. Mol Immunol (2007) 44:1935-43. doi:10.1016/j.molimm.2006.09.032

94. Reusch U, Duell J, Ellwanger K, Herbrecht C, Knackmuss SH, Fucek I, et al. A tetravalent bispecific TandAb (CD19/CD3), AFM11, efficiently recruits T cells for the potent lysis of CD19(+) tumor cells. MAbs (2015) 7:584-604. doi:10.1080/19420862.2015.1029216

95. Wu J, Fu J, Zhang M, Liu D. AFM13: a first-in-class tetravalent bispecific anti-CD30/CD16A antibody for NK cell-mediated immunotherapy. J Hematol Oncol (2015) 8:96. doi:10.1186/s13045-015-0188-3

96. Reusch U, Burkhardt C, Fucek I, Le Gall F, Le Gall M, Hoffmann K, et al. A novel tetravalent bispecific Tand Ab (CD30/CD16A) efficiently recruits NK cells for the lysis of CD30+ tumor cells. MAbs (2014) 6:728-39. doi:10.4161/ mabs. 28591

97. Rothe A, Sasse S, Topp MS, Eichenauer DA, Hummel H, Reiners KS, et al. A phase 1 study of the bispecific anti-CD30/CD16A antibody construct AFM13 in patients with relapsed or refractory Hodgkin lymphoma. Blood (2015) 125:4024-31. doi:10.1182/blood-2014-12-614636

98. Ying T, Feng Y, Wang Y, Chen W, Dimitrov DS. Monomeric IgG1 Fc molecules displaying unique Fc receptor interactions that are exploitable to treat inflammation-mediated diseases. MAbs (2014) 6:1201-10. doi:10.4161/ mabs. 29835

99. Mancardi DA, Albanesi M, Jönsson F, Iannascoli B, Van Rooijen N, Kang X, et al. The high-affinity human IgG receptor FcgammaRI (CD64) promotes IgG-mediated inflammation, anaphylaxis, and antitumor immunotherapy. Blood (2013) 121:1563-73. doi:10.1182/blood-2012-07442541

100. Thepen T, Huhn M, Melmer G, Tur MK, Barth S. Fcgamma receptor 1 (CD64), a target beyond cancer. Curr Pharm Des (2009) 15:2712-8. doi:10.2174/138161209788923967

101. van der Poel CE, Spaapen RM, van de Winkel JG, Leusen JH. Functional characteristics of the high affinity IgG receptor, FcgammaRI. J Immunol (2011) 186:2699-704. doi:10.4049/jimmunol.1003526

102. Wynn TA, Chawla A, Pollard JW. Macrophage biology in development, homeostasis and disease. Nature (2013) 496:445-55. doi:10.1038/ nature 12034

103. Ying T, Ju TW, Wang Y, Prabakaran P, Dimitrov DS. Interactions of IgG1 $\mathrm{CH} 2$ and $\mathrm{CH} 3$ domains with FcRn. Front Immunol (2014) 5:146. doi:10.3389/ fimmu.2014.00146

104. Ishino T, Wang M, Mosyak L, Tam A, Duan W, Svenson K, et al. Engineering a monomeric Fc domain modality by N-glycosylation for the half-life extension of biotherapeutics. J Biol Chem (2013) 288:16529-37. doi:10.1074/jbc. M113.457689

105. Gong R, Vu BK, Feng Y, Prieto DA, Dyba MA, Walsh JD, et al. Engineered human antibody constant domains with increased stability. J Biol Chem (2009) 284:14203-10. doi:10.1074/jbc.M900769200

106. Gong R, Wang Y, Feng Y, Zhao Q, Dimitrov DS. Shortened engineered human antibody $\mathrm{CH} 2$ domains: increased stability and binding to the human neonatal Fc receptor. J Biol Chem (2011) 286:27288-93. doi:10.1074/jbc. M111.254219

107. Ying T, Wang Y, Feng Y, Prabakaran P, Gong R, Wang L, et al. Engineered antibody domains with significantly increased transcytosis and half-life in macaques mediated by FcRn. MAbs (2015) 7:922-30. doi:10.1080/1942086 2.2015.1067353

108. Gong R, Wang Y, Ying T, Dimitrov DS. Bispecific engineered antibody domains (nanoantibodies) that interact noncompetitively with an HIV-1 neutralizing epitope and FcRn. PLoS One (2012) 7:e42288. doi:10.1371/ journal.pone.0042288

109. Ying T, Chen W, Feng Y, Wang Y, Gong R, Dimitrov DS. Engineered soluble monomeric IgG1 CH3 domain: generation, mechanisms of function, and implications for design of biological therapeutics. J Biol Chem (2013) 228:25154-64. doi:10.1074/jbc.M113.484154 
110. Wozniak-Knopp G, Bartl S, Bauer A, Mostageer M, Woisetschläger M, Antes B, et al. Introducing antigen-binding sites in structural loops of immunoglobulin constant domains: Fc fragments with engineered HER2/ neu-binding sites and antibody properties. Protein Eng Des Sel (2010) 23:289-97. doi:10.1093/protein/gzq005

111. Kainer M, Antes B, Wiederkum S, Wozniak-Knopp G, Bauer A, Rüker F, et al. Correlation between CD16a binding and immuno effector functionality of an antigen specific immunoglobulin Fc fragment (Fcab). Arch Biochem Biophys (2012) 526:154-8. doi:10.1016/j.abb.2012.05.010

112. Woisetschlager M, Antes B, Borrowdale R, Wiederkum S, Kainer M, Steinkellner $\mathrm{H}$, et al. In vivo and in vitro activity of an immunoglobulin $\mathrm{FC}$ fragment (Fcab) with engineered Her-2/neu binding sites. Biotechnol J (2014) 9:844-51. doi:10.1002/biot.201300387

113. Traxlmayr MW, Lobner E, Hasenhindl C, Stadlmayr G, Oostenbrink C, Rüker $\mathrm{F}$, et al. Construction of $\mathrm{pH}$-sensitive Her2-binding IgG1-Fc by directed evolution. Biotechnol J (2014) 9:1013-22. doi:10.1002/biot.201300483

114. Leung KM, Batey S, Rowlands R, Isaac SJ, Jones P, Drewett V, et al. A HER2specific modified $\mathrm{Fc}$ fragment (Fcab) induces antitumor effects through degradation of HER2 and apoptosis. Mol Ther (2015) 23:1722-33. doi:10.1038/ mt.2015.127

115. Holliger P, Hudson PJ. Engineered antibody fragments and the rise of single domains. Nat Biotechnol (2005) 23:1126-36. doi:10.1038/nbt1142

116. Hladnik L, Augustin K, DeFrates S. Advancements in therapy for acute lymphoblastic leukemia: blinatumomab. J Adv Pract Oncol (2016) 7:76-82. doi:10.6004/jadpro.2016.7.1.6

117. Sharkey RM, Cardillo TM, Rossi EA, Chang CH, Karacay H, McBride WJ, et al. Signal amplification in molecular imaging by pretargeting a multivalent, bispecific antibody. Nat Med (2005) 11:1250-5. doi:10.1038/nm1322

118. Sharkey RM, Rossi EA, McBride WJ, Chang CH, Goldenberg DM. Recombinant bispecific monoclonal antibodies prepared by the dockand-lock strategy for pretargeted radioimmunotherapy. Semin Nucl Med (2010) 40:190-203. doi:10.1053/j.semnuclmed.2009.12.002
119. Andersen JT, Sandlie I. The versatile MHC class I-related FcRn protects IgG and albumin from degradation: implications for development of new diagnostics and therapeutics. Drug Metab Pharmacokinet (2009) 24:318-32. doi:10.2133/dmpk.24.318

120. Herrington-Symes AP, Farys M, Khalili H, Brocchini S. Antibody fragments: prolonging circulation half-life special issue-antibody research. Adv Biosci Biotechnol (2013) 4:689-98. doi:10.4236/abb.2013.45090

121. Müller D, Karle A, Meissburger B, Hofig I, Stork R, Kontermann RE. Improved pharmacokinetics of recombinant bispecific antibody molecules by fusion to human serum albumin. J Biol Chem (2007) 282:12650-60. doi:10.1074/jbc. M700820200

122. Plückthun A, Pack P. New protein engineering approaches to multivalent and bispecific antibody fragments. Immunotechnology (1997) 3:83-105. doi:10.1016/S1380-2933(97)00067-5

123. Haraldsson B, Nyström J, Deen WM. Properties of the glomerular barrier and mechanisms of proteinuria. Physiol Rev (2008) 88:451-87. doi:10.1152/ physrev.00055.2006

124. Yu YJ, Atwal JK, Zhang Y, Tong RK, Wildsmith KR, Tan C, et al. Therapeutic bispecific antibodies cross the blood-brain barrier in nonhuman primates. Sci Transl Med (2014) 6:261ra154. doi:10.1126/scitranslmed.3009835

Conflict of Interest Statement: The authors declare that the research was conducted in the absence of any commercial or financial relationships that could be construed as a potential conflict of interest.

Copyright (c) 2017 Liu, Saxena, Sidhu and Wu. This is an open-access article distributed under the terms of the Creative Commons Attribution License (CC BY). The use, distribution or reproduction in other forums is permitted, provided the original author(s) or licensor are credited and that the original publication in this journal is cited, in accordance with accepted academic practice. No use, distribution or reproduction is permitted which does not comply with these terms. 